\title{
Identification of TCERG1 as a new genetic modulator of TDP-43 production in Drosophila
}

\author{
Marine Pons ${ }^{1}$, Silvia Prieto ${ }^{2}$, Laetitia Miguel ${ }^{1}$, Thierry Frebourg ${ }^{1,3}$, Dominique Campion ${ }^{1,4}$, Carles Suñé ${ }^{2}$ and \\ Magalie Lecourtois ${ }^{1^{*}}$
}

\begin{abstract}
TAR DNA-binding protein-43 (TDP-43) is a ubiquitously expressed DNA-/RNA-binding protein that has been linked to numerous aspects of the mRNA life cycle. Similar to many RNA-binding proteins, TDP-43 expression is tightly regulated through an autoregulatory negative feedback loop. Cell function and survival depend on the strict control of TDP-43 protein levels. TDP-43 has been identified as the major constituent of ubiquitin-positive inclusions in patients with Amyotrophic Lateral Sclerosis (ALS) and Frontotemporal Lobar Degeneration (FTLD). Several observations argue for a pathogenic role of elevated TDP-43 levels in these disorders. Modulation of the cycle of TDP-43 production might therefore provide a new therapeutic strategy. Using a Drosophila model mimicking key features of the TDP-43 autoregulatory feedback loop, we identified CG42724 as a genetic modulator of TDP-43 production in vivo. We found that CG42724 protein influences qualitatively and quantitatively the TDP-43 mRNA transcript pattern. CG42724 overexpression promotes the production of transcripts that can be efficiently released into the cytoplasm for protein translation. Importantly, we showed that TCERG1, the human homolog of the Drosophila CG42724 protein, also caused an increase of TDP-43 protein steady-state levels in mammalian cells. Therefore, our data suggest the possibility that targeting TCERG1 could be therapeutic in TDP-43 proteinopathies.
\end{abstract}

Keywords: TDP-43, Autoregulation, ALS, FTLD, TCERG1, Drosophila

\section{Introduction}

In 2006, TAR DNA-binding protein-43 (TDP-43) was identified as the major constituent of ubiquitin-positive inclusions in patients with Amyotrophic Lateral Sclerosis (ALS) and Frontotemporal Lobar Degeneration (FTLD) $[2,51]$. In sporadic and familial FTLD/ALS patients, TDP-43 is the most recurrent pathological constituent [70]. TDP-43 proteinopathy can be present in up to $97 \%$ of ALS patients, and can be noted in up to $50 \%$ of FTLD cases. FTLD-TDP (FTLD with TDP-43 positives inclusions) represents the most frequent FTLD subtypes. Multiple studies identified mutations in the TARDBP/ TDP-43 gene in patients with FTLD/ALS [12, 37, 41, 65, $73]$, demonstrating that TDP-43 not only represents a pathological hallmark, but also plays a causative role in

\footnotetext{
* Correspondence: magalie.lecourtois@univ-rouen.fr

${ }^{1}$ Normandie University, UNIROUEN, Inserm, U1245, IRIB, Rouen, France

Full list of author information is available at the end of the article
}

FTLD/ALS physiopathology. Today, more than 50 missense TARDBP mutations have been described [38].

Besides FTLD and ALS, some degree of neuronal TDP-43 pathology has also been reported in a variety of additional neurodegenerative diseases, including Alzheimer's disease (up to $60 \%$ of the patients) [1,36], corticobasal degeneration (CBD) [72], progressive supranuclear palsy (PSP) [80], Parkinson's disease [18] and Huntington's disease [23, 62].

Whatever the disease, pathological TDP-43 manifestations in neurons and glia include the accumulation of insoluble, ubiquitinated and hyperphosphorylated TDP-43 inclusions in the cytoplasm, with a concomitant depletion of TDP-43 from the nucleus [14, 24, 73]. Biochemical analysis of insoluble protein extracts isolated from patient brain tissue also revealed that pathological TDP-43 proteins are partially cleaved to generate carboxy-terminal fragments $[2,51]$.

(c) The Author(s). 2018 Open Access This article is distributed under the terms of the Creative Commons Attribution 4.0 International License (http://creativecommons.org/licenses/by/4.0/), which permits unrestricted use, distribution, and 
TDP-43 is a ubiquitously expressed DNA-/RNA-binding protein [52]. The protein predominantly resides in the nucleus, but is capable of nucleocytoplasmic shuttling $[7,79]$. TDP-43 has been linked to numerous aspects of the mRNA life cycle, including transcription, pre-mRNA splicing, mRNA stability, transport, and mRNA translation [22]. TDP-43 also regulates non-coding RNAs (miRNAs, lncRNAs, etc.). Similar to many RNA-binding proteins, TDP-43 expression is tightly regulated through an autoregulatory negative feedback loop. The TDP-43 protein regulates its own protein levels by binding to a sequence called TDPBR (for TDP-43 binding region) in the 3 ' UTR region of its cognate mRNA $[5,6,8,42,54]$. The TDP-43 pre-mRNA contains multiple alternative introns as well as polyadenylation signals in its last intron (Additional file 1: Figure S1). In steady-state conditions, most TDP-43 production within cells comes from the transcript that uses the optimal polyadenylation site pA1. When TDP-43 concentration rises, increased binding of TDP-43 proteins on the $T D P B R$ region interferes with the selection of $\mathrm{pA} 1$ and promotes the excision of an alternatively spliced intron (intron 7) containing the pA1 polyadenylation site, and the use of distal suboptimal polyadenylation sites. The resulting isoforms were shown to be retained in the nucleus (thus not available for protein synthesis) or subjected to nonsense-mediated mRNA decay.

Cell function and survival depend on the strict control of TDP-43 protein levels. Numerous studies showed that the perturbation of TDP-43 levels by either increasing or decreasing TDP-43 in animal and cellular models brings severe consequences [17, 32, 44, 61, 71]. Furthermore, several studies have observed an increase in TDP-43 mRNA and protein levels in various tissues (central nervous system, cerebrospinal fluid, plasma ...) of patients suffering from FTLD-TDP or ALS [20, 29, 35, 37, 39, 46, $56,66,69,74,77]$. Interestingly, TDP-43 mutant proteins show various degrees of prolonged half-life and enhanced stability $[4,76]$, which could lead to an elevated steady-state levels of TDP-43 proteins [9, 64]. Recently, it has been shown in a knock-in mouse model that the FTLD/ALS-linked Q331K mutation perturbs TDP-43 autoregulation, leading to increased TDP-43 expression and gain of function [78]. Altogether, these observations argue for a pathogenic role of elevated TDP-43 levels. Modulation of the TDP-43 production cycle might therefore provide a new therapeutic strategy.

Our group recently developed new Drosophila models mimicking key features of the TDP-43 autoregulatory feedback loop, namely alternative splicing events, differential usage of polyadenylation sites, nuclear retention of the transcript and a decrease in steady-state mRNA levels [55]. These transgenic models are based on the expression of an untagged wild-type form of human
TDP-43 protein under the control of the TDPBR region. Using these animal models, we identified the Drosophila gene CG42724 as a genetic modulator of TDP-43 production in vivo. We showed that CG42724 overexpression caused a drastic increase of TDP-43 protein steady-state levels, whereas CG42724 down-regulation resulted in a decrease of TDP-43 accumulation. The study of the underlying molecular mechanisms allowed us to demonstrate that the CG42724 protein influences qualitatively and quantitatively the TDP-43_TDPBR mRNA transcripts pattern. CG42724 overexpression promotes the inclusion of the TDPBR sensor region and the production of transcripts ending at the $\mathrm{pA} 1$ polyadenylation, isoforms that can be efficiently released into the cytoplasm for protein translation. Importantly, we showed that TCERG1, the human homolog of the Drosophila CG42724 protein, also caused an increase of TDP-43 protein steady-state levels in mammalian cells.

\section{Materials and methods}

An ethics statement is not required for this work.

\section{DNA constructs}

The fusion construct GFP::TDP43 was generated using the PCR overlap extension procedure [33]. Each fragments were first generated separately. PCR-amplification of GFP cDNA was achieved with the primers 5'-CCGCTCGAG CGGCAAAATGGTGAGCAAGGGCGAGGAGC-3' and 5'-CGGTTACCCGAATATATTCAGACTTGTACAGCT CGTCCATGCCG-3'. PCR-amplification of TDP-43 cDNA was achieved with the primers 5'-CGGCATGGA CGAGCTGTACAAGTCTGAATATATTCGGGTAACC G-3' and 5'-TGCTCTAGAGCACTACATTCCCCA GCCAGAAGACTTAGAATCC-3'. Then, these overlapping fragments were both used as template in a PCR reaction, using the primers 5'-CCGCTCGAGCGGCA AAATGGTGAGCAAGGGCGAGGAGC-3' and 5'-TG CTCTAGAGCACTACATTCCCCAGCCAGAAGACTTA GAATCC-3'. The fusion GFP::TDP43 PCR product was subcloned in the pcDNA3 vector and sequenced. PCR amplification of the TDPBR region was achieved using the pUAST-TDP-43_TDPBR plasmid described in [55] and the primers 5'-TGCACTAGTTCACAGGCCGCGTCTTTGA CGGTGGG-3' and 5' $^{\prime}$ - TGCTCTAGAAAAACAAAGA CACATATTATTTAAATCAG-3'. The PCR product was then subcloned into the pcDNA3-GFP:::TDP43 vector and sequenced. The pEFBOST7-TCERG1 expression plasmid was previously described in [67]. The expressed TCERG1 protein contains the 11-amino-acid T7 epitope tag at its amino terminus.

\section{Fly genetics}

Drosophila were maintained on a 12:12 light/dark cycle on standard cornmeal-yeast agar medium at $25^{\circ} \mathrm{C}$. The 
following transgenic Drosophila strains were used in this study: UAS-FUS [19], UAS-TDP-43_TDPBR [55]. The GMR-Gal4, UAS-LacZ, UAS-CG42724 ${ }^{R N A i}$ (stock \#33737 and \#55357) lines were obtained from Bloomington Stock Center. Detailed fly genotypes are listed in Additional file 2.

\section{Cell culture and transfections}

HEK293T cells were grown and maintained as previously described [59]. Transfections were performed in 35- $\mathrm{mm}$ 6-well plates. Each plate was seeded with approximately $1 \times 10^{6}$ cells $20 \mathrm{~h}$ prior to transfection. The cells were grown to approximately 60 to $70 \%$ confluence and transfected with the appropriate amounts of the indicated constructs by using the lipofectamine 2000 reagent (Invitrogen, Carlsbad, CA, USA) according to the manufacturer's protocol. Approximately $48 \mathrm{~h}$ after transfection, the cells were harvested and processed for Western blotting analysis.

\section{Production of the TCERG1 antibody}

To express TCERG1 protein in Escherichia coli, we amplified two segments containing amino and carboxyl sequences of the TCERG1 cDNA and cloned in frame into the expression vector PGEX2TK (Pharmacia Biotech, Piscataway, NJ, USA). The proteins were expressed as GST fusions under previously published conditions [26]. Purified fusion proteins were used to generate in-house polyclonal antibodies in guinea pigs following standard protocols.

\section{Mapping of the P\{y+\}UAS transposon by inverse PCR}

Genomic DNA was prepared from 10 flies using the DNeasy Blood and Tissue kit (Qiagen, Hilden, Germany) according to the manufacturer's instructions. Purified genomic DNA $(\sim 5 \mu \mathrm{g})$ was digested by MspI or HinpI (New England Biolabs Inc., Ipswich, MA, USA) for 2-3 h. Digested DNA $(\sim 20.5 \mu \mathrm{g})$ was self-ligated (T4 DNA Ligase, New England Biolabs Inc.) overnight at $4{ }^{\circ} \mathrm{C}$ in a total volume of $150 \mu \mathrm{L}$. To isolate P-element insertion sequence, primer pair OUY31 (5'ATTGATTCACTTTA ACTTGCAC 3') and OUY52 (5'ACACAACCTTTCCT CTCAACAA 3') was used. The PCR protocol was $95^{\circ} \mathrm{C}$ $5 \mathrm{~min}, 34$ cycles of $95^{\circ} \mathrm{C} 30 \mathrm{~s}, 55^{\circ} \mathrm{C} 1 \mathrm{~min}, 68^{\circ} \mathrm{C} 2 \mathrm{~min}$, followed by $68^{\circ} \mathrm{C} 10 \mathrm{~min}$. PCR products were sequenced with OUY31 or OUY52.

\section{$3^{\prime} \mathrm{RACE}$, reverse transcription-quantitative multiplex PCR of short fluorescent fragment (RT-QMPSF) and data calculation}

Total RNA extraction and quantification of overall TDP-43 or CG42724 mRNA steady-state levels were performed as previously described in [55]. To characterize and quantify the relative abundance of TDP-43 mRNA splice isoform transcripts, we amplified the 3' ends of the TDP-43 transcripts using the " 3 ' RACE System for Rapid Amplification of cDNA Ends" kit (Invitrogen), according to the manufacter's instructions. Briefly, $500 \mathrm{ng}$ of RNA were converted to cDNA. For qualitative studies (agarose gel electrophoresis), the PCR was performed with $2 \mu \mathrm{L}$ of the first-strand reaction, $0.2 \mu \mathrm{M}$ of AUAP primer and $0.2 \mu \mathrm{M}$ of TDP-43 F3 primer, using the Diamond Taq polymerase (Eurogentec, Liège, Belgium), as recommended by the manufacturer. A touchdown method was used with a DNA Engine (PTC-200) Peltier Thermal Cycler (Bio-Rad Laboratories, Hercules, CA). Cycling times were: $3 \mathrm{~min}$ at $95^{\circ} \mathrm{C}$, followed by 40 cycles including (i) denaturation at $95^{\circ} \mathrm{C}$ for $10 \mathrm{~s}$, (ii) annealing beginning at $65^{\circ} \mathrm{C}$ and ending at $55^{\circ} \mathrm{C}$ for $20 \mathrm{~s}$, and (iii) extension at $72^{\circ} \mathrm{C}$ for $5 \mathrm{~min}$, with a final extension at $72^{\circ} \mathrm{C}$ for $10 \mathrm{~min}$. For quantitative studies, the PCR was performed with $1 \mu \mathrm{L}$ of the first-strand reaction, $0.08 \mu \mathrm{M}$ of AUAP primer, $0.08 \mu \mathrm{M}$ of TDP-43 F3 primer, $0.05 \mu \mathrm{M}$ of Cyp1 primers, and $0.06 \mu \mathrm{M}$ of $R p L 13 A$ primers. Sense primers were 6-FAM-labelled. All primers were used in a single PCR reaction volume of $25 \mu \mathrm{L}$. Multiplex fluorescent PCR assays were carried out using $2 \mathrm{mM} \mathrm{MgCl} 2,1$ unit of Diamond Taq polymerase (Eurogentec) and $200 \mu \mathrm{M}$ of dNTP. After an initial cycle of denaturation at $95^{\circ} \mathrm{C}$ for $5 \mathrm{~min}, 25$ cycles were performed consisting of denaturation at $95^{\circ} \mathrm{C}$ for 10 $\mathrm{s}$, annealing at $58.8^{\circ} \mathrm{C}$ for $30 \mathrm{~s}$, and extension at $72^{\circ} \mathrm{C}$ for $1 \mathrm{~min} \mathrm{30}$, and final extension at $72^{\circ} \mathrm{C}$ for $10 \mathrm{~min}$, in a DNA engine Peltier Thermal Cycler (Bio-Rad Laboratories). Fluorescent amplicons were separated on an ABI prism 3500 Genetic Analyzer (Applied Biosystems, Foster City, CA, USA), and the resulting fluorescent profiles were analyzed using the GeneMapper 5 software (Applied Biosystems). All QMPSF analyses were performed at least in duplicate. For comparative analyses, the average peak heights obtained for TDP-43 amplicons were compared to the mean peak height obtained for the control amplicons for each genotype. The ratio obtained was set at 100 for the control genotype (GMR > TDP-43_TDPBR). TDP-43 expression levels were compared between controls and each of the other genotype by using a Student's t-test. Primers used in this study are listed in Additional file 3: Table S1.

\section{Protein extraction and immunoblot analysis}

Drosophila study: total proteins were prepared by grounding 30 adult fly heads directly in $150 \mu \mathrm{L}$ Protein Solving Buffer (PSB) (Macherey-Nagel, Düren, Germany), using the TissueLyser LT (Qiagen) through high-speed shaking $(50 \mathrm{~Hz})$ of samples in $2 \mathrm{~mL}$ microcentrifuge tubes with two $5 \mathrm{~mm}$ stainless steel beads for $2 \mathrm{~min}$. Samples were then spun down to collect the lysates, and protein concentrations were measured using the Protein Quantification Assay Kit (Macherey-Nagel). 
For sequential extraction of soluble and insoluble proteins, 30 adult fly heads or HEK293T cellular pellets were homogenized in $150 \mu \mathrm{L}$ Radio Immunoprecipitation Assay (RIPA) buffer ( $25 \mathrm{mM}$ Tris- $\mathrm{HCl} \mathrm{pH}$ 7.6, $150 \mathrm{mM} \mathrm{NaCl}, 1 \%$ NP-40, 1\% sodium deoxycholate, $0.1 \%$ SDS) (Pierce Biotechnology, Rockford, IL, USA), supplemented with a cocktail of protease inhibitors (Sigma-Aldrich) and phosphatase inhibitors (Thermo Fisher Scientific Inc.) using the TissueLyser LT (Qiagen) (two $5 \mathrm{~mm}$ stainless steel beads; $50 \mathrm{~Hz}, 2 \mathrm{~min}$ ). Samples were then spun down and the lysates transferred to clean tubes. After centrifugation $\left(11,300 \mathrm{x} \mathrm{g}, 20 \mathrm{~min}, 4^{\circ} \mathrm{C}\right)$, the supernatant (corresponding to the RIPA-soluble fraction) was reserved in a separate tube while the pellet was washed once in $50 \mu \mathrm{L}$ of RIPA. The resulting supernatant was pooled with the first one. The remaining pellet was homogenized in $200 \mu \mathrm{L}$ of urea buffer (urea $9 \mathrm{M}$, Tris- $\mathrm{HCl} 50 \mathrm{mM} \mathrm{pH} 8$, CHAPS 1\%, and a cocktail of protease and phosphatase inhibitors) and centrifuged at 11,300 $\mathrm{x}$ g for $30 \mathrm{~min}$. The supernatant was collected as the urea fraction. Protein concentrations of the soluble fraction were measured using the DC Protein Assay Kit (Bio-Rad Laboratories). Soluble and insoluble proteins were loaded for SDS-PAGE migration in a proportion of 1:1. Proteins were resolved by TGX Stain-Free 12\% gels (Bio-Rad Laboratories), and then transferred onto nitrocellulose membrane (Bio-Rad nitrocellulose Turbo transfer packs) for $7 \mathrm{~min}, 25 \mathrm{~V}, 2.5 \mathrm{~A}$ using the Trans-Blot Turbo system (Bio-Rad Laboratories). Membranes were then blocked using PBS 1x containing 5\% non-fat milk and $0.05 \%$ Tween, and then incubated with antibodies. Gel loading was normalized by Stain-Free detection of total proteins using a Geldoc ${ }^{\text {Ti }}$ EZ imager (Bio-Rad Laboratories), as recommended by the manufacturer. The Stain-Free signal obtained in each lane was quantified (ImageLab ${ }^{\text {tw }}$ software, Bio-Rad Laboratories). The following primary antibodies were used: rabbit polyclonal anti-TDP-43 (1:5000; Proteintech, Chicago, IL, USA), LacZ (1/10,000; Promega, Charbonnières-les-Bains, France), FUS (1/5000; Bethyl Laboratories, Inc. Montgomery, TX, USA), TCERG1 (1:5000). Membranes were incubated with secondary peroxidase-labelled anti-mouse, anti-guinea or anti-rabbit antibodies $(1: 10,000)$ from Jackson Immunoresearch Laboratories (WestGrove, PA, USA), and signals were detected with chemiluminescence reagents (ECL Clarity, Bio-Rad Laboratories). Signals were acquired with a GBOX (Syngene, Cambridge, UK), monitored by the Gene Snap software (Syngene). The signal intensity in each lane was quantified using the Genetools software (Syngene), and normalized with the Stain-Free signal quantified in the corresponding lane.

\section{RNA and protein subcellular fractionation}

Fifty newly-eclosed adult fly heads were ground to powder using the TissueLyser LT (Qiagen) through three one-minute cycles of high-speed shaking $(50 \mathrm{~Hz})$ in 1.5 $\mathrm{mL}$ microcentrifuge tubes with two $2.5 \mathrm{~mm}$ stainless steel beads. Samples were then gently homogenized in $240 \mu \mathrm{L}$ of fractionation buffer (Hepes $10 \mathrm{mM}, \mathrm{NaCl} 10$ $\mathrm{mM}, \mathrm{MgCl} 23 \mathrm{mM}, \mathrm{NP}-40$ 0.5\%, RNAse inhibitor $100 \mathrm{u} /$ $\mathrm{mL}$ (Promega, Fitchburg, WI, USA)) on ice and centrifuged at $100 \mathrm{x} \mathrm{g}$ for $30 \mathrm{~s}$ to spin down debris. Lysates were then centrifuged at $2300 \mathrm{x} \mathrm{g}$ for $5 \mathrm{~min}$ at $4{ }^{\circ} \mathrm{C}$ to separate nuclei from cytoplasm. Nuclei (pellet) were washed 3 times in $500 \mu \mathrm{L}$ of fractionation buffer and stored overnight at $-80^{\circ} \mathrm{C} .20 \mu \mathrm{l}$ of Sodium acetate $3 \mathrm{M}$ pH 5.2 and $600 \mu \mathrm{L}$ of Ethanol $100 \%$ were added to cytoplasmic fractions (Supernatant). Samples were vortexed vigorously and then stored at $-80{ }^{\circ} \mathrm{C}$ overnight. Cytoplasmic proteins and nucleic acids were then pelleted at $14,000 \times \mathrm{g}$ for $15 \mathrm{~min}$ at $4{ }^{\circ} \mathrm{C}$ and washed once with $500 \mu \mathrm{L}$ of Ethanol $70 \%$. Proteins and RNA derived from nuclear and cytoplasmic fractions were then extracted using the Nucleospin RNA/protein kit (Macherey-Nagel) using the manufacturer's recommendations.

\section{Statistical analysis}

All $\mathrm{n}$ reported are biological replicates. All statistical analyses were performed using a two-tailed Student's t-test with Welch's correction for unequal variances (GraphPad, San Diego, CA, USA). Data on graphs are expressed as mean values, error bars representing the standard error of the mean (SEM). For significance symbols, one asterisk means $p<0.05$, two asterisks mean $p$ $<0.01$, and three asterisks mean $p<0.001$.

\section{Results}

\section{Identification of CG42724 as a modulator of TDP-43} production

In the course of a P[UAS]-based misexpression screen for modifiers of TDP-43 production, we screened part of the UY collection [47]. For the screen, we crossed GMR-Gal4 > TDP-43_TDPBR females to UYi males and assessed the F1 progeny for TDP-43 production by western blot analysis. The GMR-Gal4 driver line is expressed in all cells of the developing and adult eyes, including the photoreceptor neurons as well as accessory pigment cells. We identified a P[UAS]-insertion line (UY5237) that significantly increased TDP-43 production (Fig. 1a). As expected western blot analysis of total protein extracts from newly-eclosed adult heads revealed a single band with an apparent molecular mass of $\sim 43 \mathrm{kDa}$ that corresponded to the predicted size of the 414 amino acid TDP-43 sequence. No signal was detected in control flies $(G M R>+)$, indicating that the human TDP-43 antibody did not recognize Drosophila proteins, including the Drosophila homolog TBPH. Normalization of the amount of TDP-43 proteins using the stain-free technology [58] showed that the $P(U Y) 5237$ element caused a 


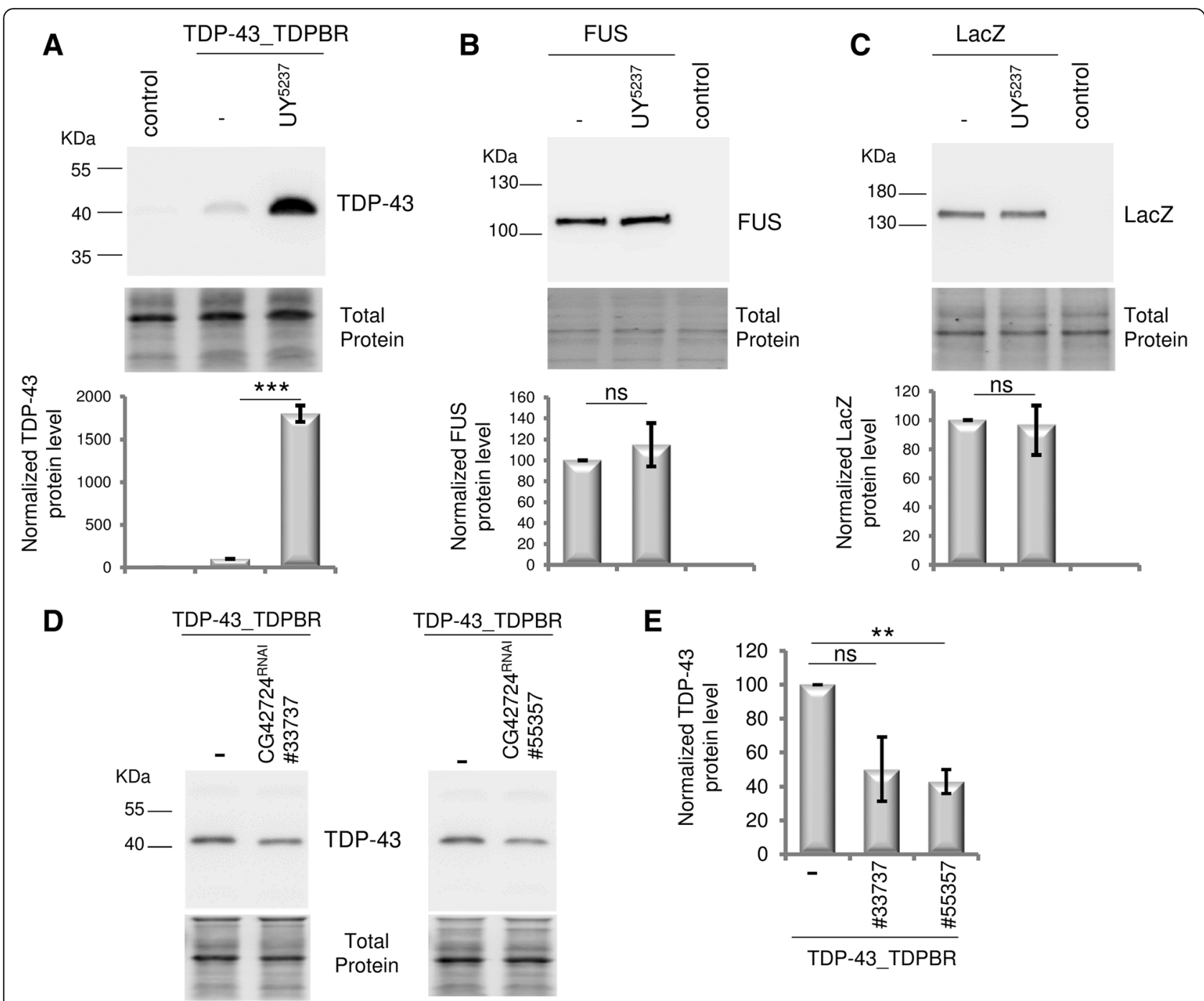

Fig. 1 CG42724 expression modulates TDP-43 production. a-c Western Blot analyses of proteins extracted from transgenic flies expressing UASTDP-43_TDPBR (a), UAS-FUS (b) or UAS-LacZ (c) constructs, in the presence or the absence of the P(UY)5237 element, under the control of the GMR-Gal4 driver line. Control flies: GMR-Gal4 > +. Expression of TDP-43, FUS and LacZ proteins was qualified using specific antibodies. Representative blots are shown $(n \geq 4)$. Total protein was used as loading control and the normalized expression of the proteins of interest is reported in the graphs (mean \pm SEM). Genotypes GMR-Gal4 > UAS-TDP-43_TDPBR, GMR-Gal4 > UAS-FUS and GMR-Gal4 > UAS-LacZ were arbitrarily set at 100 arbitrary units. The $P(U Y) 5237$ element caused a drastic increase of TDP-43 protein steady-state levels $(n=8, p=0.0001)$, but did not modify significantly FUS $(n=4, p=0.524)$ or $\operatorname{Lac} Z(n=4, p=0.822)$ expression. $\mathbf{d}$, e Western Blot analyses of total proteins extracted from transgenic flies expressing UAS-TDP-43_TDPBR with or without RNAi constructs targeting CG42724 (\#33737 or \#55357) under the control of the GMR-Gal4 driver line (d). Blots were probed with an anti-TDP-43 antibody and representative blots are presented $(n=4)$. Total protein was used as the loading control. The normalized expression of the TDP-43 protein is reported in the graphs (mean \pm SEM) (e). Control (GMR-Gal4 > UAS-TDP-43_TDPBR) waS

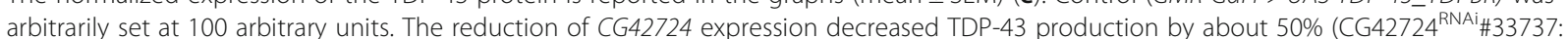
$n=4, p=0.0659, C G 42724^{\mathrm{RNA}} \# 55357: n=4, p=0.0040$ ). a-e Protein levels were compared between both genotypes by using Student's t-test. ns: not significant, ${ }^{* *}: p<0.01{ }^{* * *}: p<0.001$

drastic increase $(\sim 18$-fold $)$ of TDP-43 protein steadystate levels $(p=0.0001)$. In contrast, the $P(U Y) 5237$ element did not modify significantly FUS $(p=0.524)$ (Fig. 1b) and LacZ ( $p=0.822$ ) (Fig. 1c) expression.

PCR rescue experiments were then performed to identify the insertion point and orientation of the transposon by comparing the sequence of the flanking genomic DNA to the Drosophila genome sequence database. The UY5237 line corresponds to a $P\{y+\} U A S$ transposon inserted $170 \mathrm{bp}$ upstream of the CG42724 gene, potentially driving transcription of the gene in a Gal4-dependent manner (Fig. 2a). To validate that the transposon insertion in the UY5237 line leads to upregulation of the related downstream gene in the presence of Gal4, we performed an RT-QMPSF (reverse transcription-quantitative multiplex $\mathrm{PCR}$ of short fluorescent fragments). This assay is based on simultaneous 


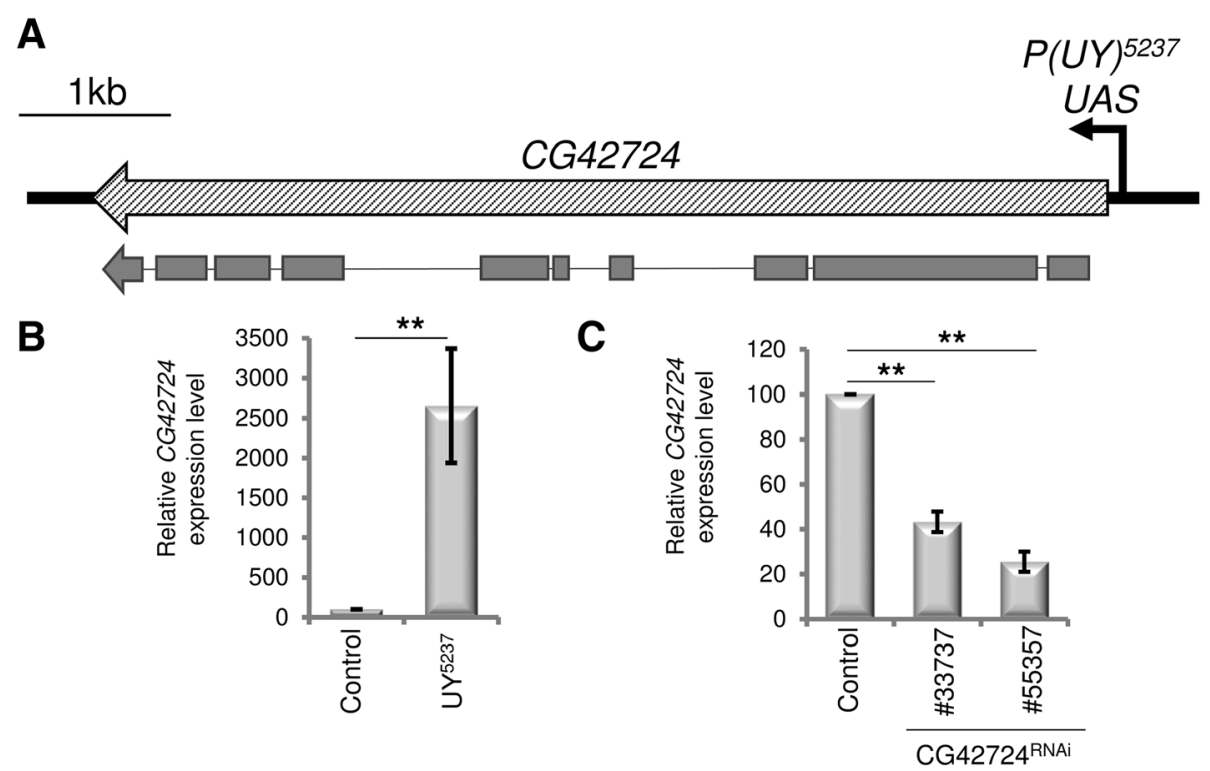

Fig. 2 Characterization of the transposon UY5237 line. a The CG42724 transcription unit is represented by the filled rectangle. Exons are represented by rectangles below the transcription unit, and introns as a line. The arrow represents the orientation of transcription from the P\{y +$\} \cup A S$ transposon in the UY5237 transgenic line. Scale bar (upper right) is 1000 bp. Schematic representation adapted from FlyBase. (b, c) Quantification of the CG42724 mRNA steady-state levels by RT-QMPSF experiments. Total RNA were extracted from GMR-Gal4 > + (control), GMR-Gal4 > UY5237, GMR-Gal4 > UASCG42724 $4^{R N A i} \# 33737$ or GMR-Gal4 > UAS-CG42724 ${ }^{R N A i}$ \#55357 transgenic flies. The graph represents mean \pm SEM after normalization with Cyp 1 (reference gene). Controls were arbitrarily set at 100 arbitrary units. The mRNA levels were compared between both genotypes by using Student's t-test. **: $p<0.01$. b CG42724 mRNA expression in flies heterozygous for the UY5237 transposon was significantly increased, compared to control flies $(n=8, p=0.009$ ). c Expression of RNAi constructs targeting CG42724 (\#33737 or \#55357) significantly reduced CG42724 mRNA steady-state levels, relative to control flies (CG42724 ${ }^{\text {RNAi}} \# 33737 n=4, p=0.0011$, CG42724 ${ }^{R N A i} \# 55357 n=3, p=0.0037$ )

PCR amplification of short fluorescent fragments and allows the comparative quantitative analysis of mRNA. We compared the levels of CG42724 transcripts in GMRGal4 > + and GMR-Gal4 > UY5237 Drosophila heads. We indeed observed a significant upregulation of the CG42724 transcripts (about 27 fold, $p=0.009$ ) in GMR-Gal4 > UY5237 flies, compared to control flies (GMR-Gal4 $>+$ ) (Fig. 2b, Additional file 4: Figure S2).

To confirm the role of CG42724 on TDP-43 proteins steady-state levels, we then tested two independent CG42724 ${ }^{R N A i}$ Drosophila transgenic lines that target two different regions of the CG42724 mRNA (Additional file 4: Figure S2A). First, we validated the efficiency of both RNAi by assessing the RNAi-mediated decrease of CG42724 expression by RT-QMPSF. We found that expression of RNAi constructs targeting CG42724 significantly reduced CG42724 mRNA steady-state levels (CG42724 ${ }^{\text {RNAi\#33737 }} p=0.0011, C G 42724^{\text {RNAi\#55357 }} p=$ 0.0037) (Fig. 2c). Then, we quantified TDP-43 proteins steady-state levels and we found that the reduction of CG42724 expression decreased TDP-43 production by about $50 \% \quad\left(C G 42724^{\text {RNAi\#33737 }}, \quad p=0.0659\right.$, CG42724 ${ }^{R N A i \# 55357}, p=0.0040$ ) (Fig. 1d,e). The opposing effects observed on TDP-43 production from RNAi and overexpression approaches strongly argue that CG42724 acts as a genetic modulator of TDP-43 production.
Effect of the CG42724-mediated regulation of TDP-43 production on TDP-43 solubility and TDP-43 phenotypic severity

We next assessed whether CG42724-mediated increased expression of TDP-43 resulted in cellular toxicity in Drosophila retina. We observed that flies carrying a single copy of the TDP-43_TDPBR construct with the $P(U Y) 5237$ element displayed no obvious external phenotype, compared to control flies (Additional file 5: Figure S3). However, when we maximized TDP-43 protein expression by making use of flies bearing two copies each of the TDP-43_TDPBR transgene, we found that CG42724 co-expression caused strong synergistic effects (Fig. 3a). Compared to control eyes, TDP-43_TDPBR ${ }^{x 2}$ expression induced no discernible phenotype. In contrast, CG42724 overexpression resulted in a rough-eye phenotype. Co-expression of TDP-43_TDPBR ${ }^{x 2}$ and CG42724 in the eye was associated with a more severely disorganized rough-eye phenotype.

Interestingly, we also observed that CG42724 overexpression is associated with the appearance of TDP-43 high-molecular weight (HMW) species (Fig. 3b). Adult heads from GMR $>T D P-43 \_T D P B R^{x 2}$ or $G M R>$ TDP-43_TDPBR $R^{x 2}, U Y 5237$ transgenic flies were extracted with RIPA buffer followed by extraction in urea buffer to 


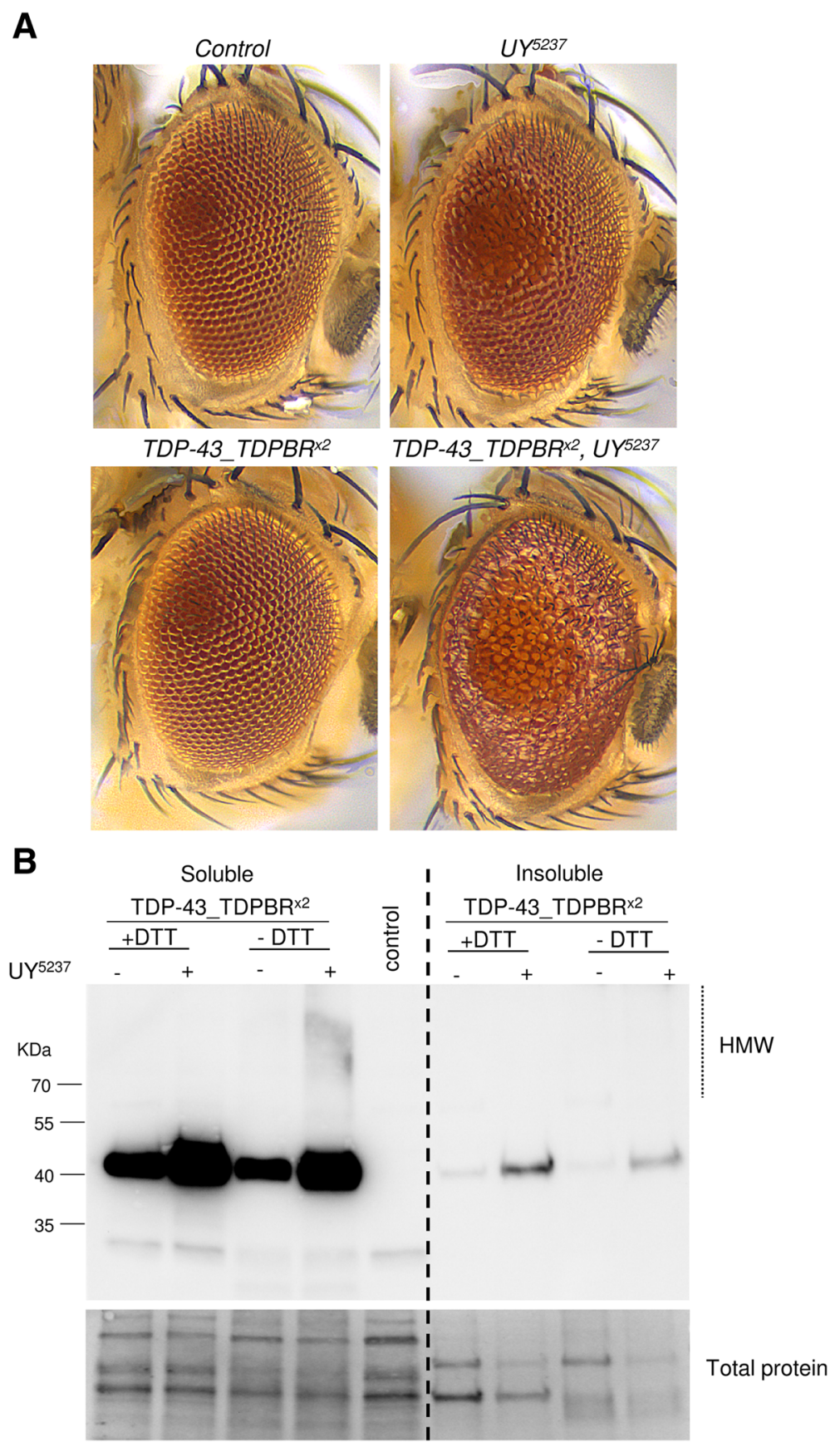

Fig. 3 CG42724-mediated increase of TDP-43 production results in the appearance of insoluble TDP-43 aggregates and causes cellular toxicity in Drosophila retina. a Light micrographs of newborn Drosophila adult eyes raised at $23^{\circ} \mathrm{C}$. Compared to control flies (GMR-Gal4 $>+$ ), TDP-43_TDPBR ${ }^{\times 2}$ $\left(G M R-G a l 4^{\times 2}>\right.$ UAS-TDP-43_TDPBR $\left.{ }^{\times 2}\right)$ expression alone triggered no structural defects. Flies overexpressing CG42724 (GMR-Gal4 ${ }^{\times 2}>$ UY5237) displayed alteration of the external eye aspect ("rough-eye phenotype"). Coexpression of CG42724 and TDP-43_TDPBR ${ }^{\times 2}$ (GMR-Gal4 ${ }^{\times 2}>$ UAS-TDP-43_TDPBR $^{\times 2}$, UY5237) enhanced the severity of the "rough-eye phenotype" in a synergistic manner. b Western blot analyses of TDP-43 proteins extracted from flies expressing TDP-43_TDPBR ${ }^{\times 2}$ with or without the P(UY)5237 transposon under the control of the GMR-Gal4 driver, and control flies bearing only the GMR-Gal4 transgene. Proteins were sequentially extracted in RIPA (soluble) and Urea (insoluble) buffers. Samples were loaded with (+ DTT) or without (- DTT) reducing agent. Blots were probed with an anti-TDP-43 antibody and representative blots are presented $(n=4)$. Total protein was used as the loading control. CG42724-mediated increased expression of TDP-43 resulted in appearance of DTT-sensitive high molecular weight (HMW) species

recover insoluble TDP-43. Samples were loaded with or without reducing agent (-DTT) to prevent dissociation of putative HMW forms. Only a faint signal was detected in the insoluble urea fraction, indicating that TDP-43 species were mainly recovered as soluble forms in Drosophila. As expected, the expression of CG42724 increased the 
TDP-43 protein steady-state levels. TDP-43 proteins were detected as either full-length monomeric forms or HMW species, with TDP-43 proteins being the most prone to form aggregates in the presence of the UY5237 transgene. When samples were analysed in the presence of the reducing agent (+DTT), we observed a decrease of the HMW forms and, concomitantly, an increase of TDP-43 monomeric species, indicating that these complexes were indeed DTT-sensitive. Altogether, these data showed that CG42724-mediated increased expression of TDP-43 results in the appearance of TDP-43 HMW species and is associated with cellular toxicity in Drosophila retina.

\section{CG42724-mediated regulation of TDP-43 production depends mainly on the presence of the TDPBR region}

To address the molecular mechanisms underlying these genetic interactions, we first determined whether the TDPBR region contributes to the CG42724-mediated regulation of TDP-43 protein production using the $U A S-T D P-43$ construct (no TDPBR region) previously described in [55]. Western blot analysis of total protein extracts showed that, in contrast to what we observed with the UAS-TDP-43_TDPBR construct (about 18 fold, $p=$ 0.0001 ), overexpression of CG42724 caused only a 2-fold increase in TDP-43 protein steady-state levels $(p=0.0002)$ (Fig. 4), demonstrating that CG42724-mediated regulation of TDP-43 protein production predominantly depends on the presence of the TDPBR region.
CG42724 expression regulates TDP-43 production by regulating alternative splicing events and nucleocytoplasmic export of TDP-43 mRNAs

We previously demonstrated that the self-regulatory process of TDP-43 protein steady-state levels in flies depends on alternative splicing events, differential usage of polyadenylation sites, nuclear retention of the transcript and a decrease in steady-state mRNA levels [55]. Interestingly, the CG42724 gene encodes a homolog of the human TCERG1 (Transcription elongation regulator 1) gene (Additional file 6: Figure S4). Human TCERG1 is a nuclear protein that has been implicated in transcription and pre-mRNA-splicing regulation. TCERG1 physically couples transcription elongation and splicing events by interacting with splicing factors and the RNA polymerase II. We therefore sought to determine which of the cellular processes involved in the TDP-43 autoregulatory feedback loop were affected by CG42724 overexpression.

We first evaluated whether changes in TDP-43 steady-state mRNA levels could account for the observed modulation at the protein level. We performed RT-QMPSF experiments on GMR $>$ TDP-43_TDPBR or GMR > TDP-43_TDPBR, UY5237 transgenic flies, using pairs of primers that can detect all isoforms of the TDP-43 mRNA (F1/R1 and F2/R2, Additional file 7: Figure S5A and Additional file 3: Table S1). As shown in Fig. $5 \mathrm{a}$ and Additional file 7: Figure S5B, modulation of CG42724 expression resulted in a slight, but not significant statistical increase of overall TDP-43 mRNA levels compared to the control $(p=0.055)$.
A

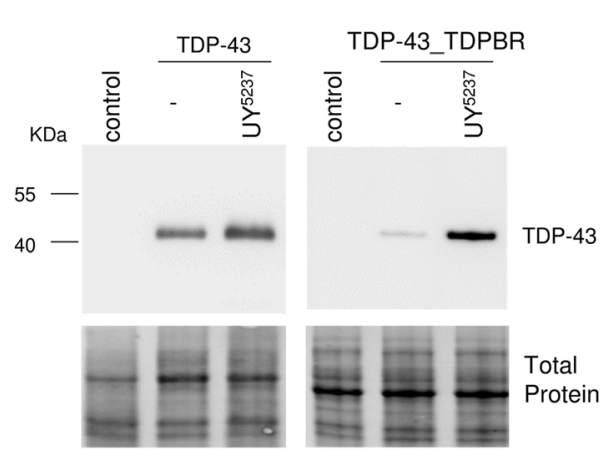

B

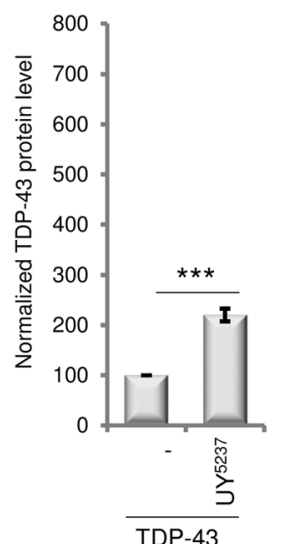

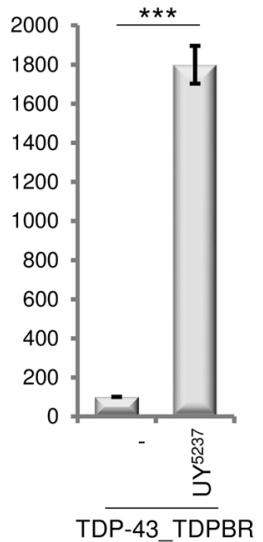

Fig. 4 CG42724-mediated regulation of TDP-43 production depends mainly on the presence of the TDPBR region. Western Blot analyses of proteins extracted from transgenic flies expressing the UAS-TDP-43_TDPBR or the UAS-TDP-43 constructs, in the presence or the absence of the P(UY)5237 element, under the control of the GMR-Gal4 driver line. Control flies: GMR-Gal4 > +. a Blots were probed with an anti-TDP-43 antibody and representative blots are presented $(n \geq 7)$. Total protein was used as the loading control. $\mathbf{b}$ The normalized expression of the TDP-43 protein is reported in the graphs (mean \pm SEM). Genotypes GMR-Gal4 > UAS-TDP-43_TDPBR and GMR-Gal4 > UAS-TDP-43 were arbitrarily set at 100 arbitrary units. Protein levels were compared between both genotypes by using Student's t-test. ***: $p<0.001$. The $P(U Y) 5237$ element caused a drastic increase of TDP-43 protein steady-state levels in the context of the UAS-TDP-43_TDPBR construct $(n=8, p=0.0001)$, but only a slight rise when the UAS-TDP-43 construct was expressed $(n=7, p=0.0002)$ 
A

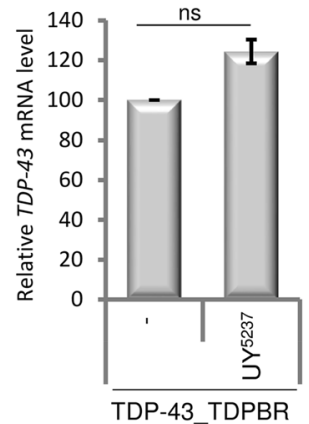

C

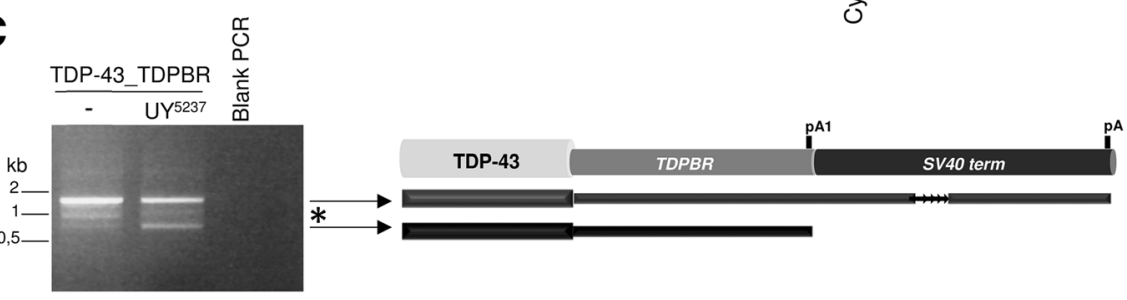

D

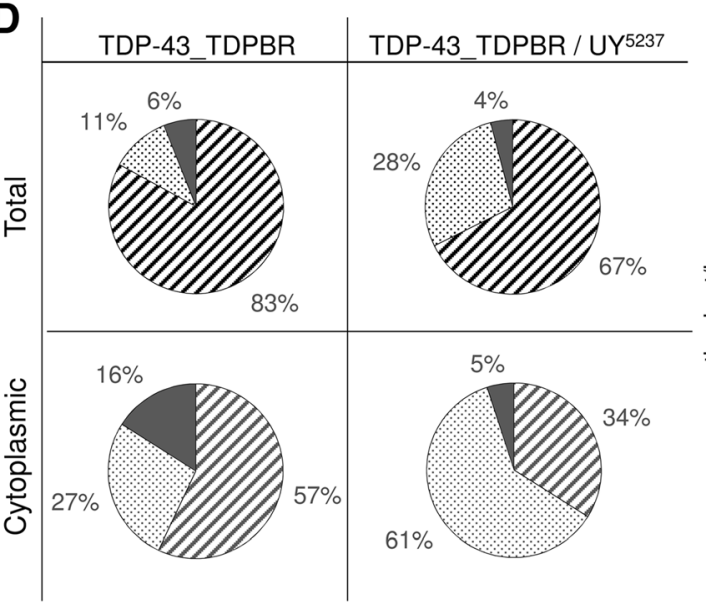

B

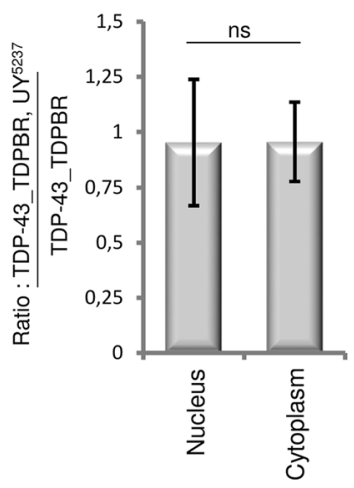

$\mathbf{E}$

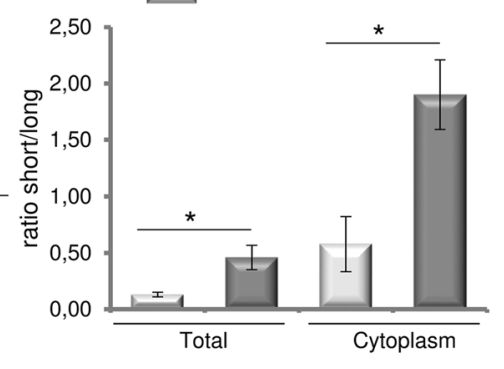

\section{$\square$ Long isoform $\square$ Intermediate isoform $\$$ Short isoform}

Fig. 5 CG42724 influences TDP-43 production by regulating qualitatively and quantitatively the pattern and the nucleocytoplasmic export of TDP43 mRNA transcripts. a Quantification of the TDP-43 mRNA steady-state levels by RT-QMPSF experiments in GMR-Gal4 > UAS-TDP-43_TDPBR and GMR-Gal4 > UAS-TDP-43_TDPBR, UY5237 flies. The graph represents mean \pm SEM after normalization with Cyp1 (reference gene). Controls were arbitrarily set at 100 arbitrary units. The mRNA levels were compared between both genotypes by using Student's t-test. ns: not significant. CG42724 expression did not significantly influence TDP-43 mRNA steady-state levels $(n=4, p=0.055)$. b Total RNA from cytoplasmic and nuclear fractions were isolated from GMR > TDP-43_TDPBR or GMR > TDP-43_TDPBR, UY5237 transgenic flies. The graph represents mean \pm SEM of TDP-43 mRNA levels detected by RT-QMPSF experiments, after normalization with Cyp 1. Controls were arbitrarily set at 100 arbitrary units. TDP-43 expression levels were compared by using Student's t-test. ns: not significant. CG42724 expression did not modulate global TDP-43 mRNA nucleocytoplasmic export $(n=3, p=0.992)$. c Agarose gel electrophoresis of the PCR products in the $3^{\prime}$ RACE analysis. The $3^{\prime}$ RACE experiments were performed using RNA described in (a). Left: representative gel image $(n>10)$. Expression of CG42724 resulted in a qualitative distinct pattern. Right: schematic representation of the long and the short TDP-43_TDPBR mRNA variants detected in flies. $\mathbf{d}$ Quantification of the relative abundance of the TDP-43_TDPBR mRNA variants by 3' RACE PCR amplification combined to QMPSF methodology, in GMR-Gal4 > UAS-TDP43_TDPBR and GMR > TDP-43_TDPBR, UY5237 transgenic flies. The mRNA fractions from the cytoplasm and from whole cells (total RNA) were analyzed. Three fluorescent peaks corresponding to a short isoform, intermediate species and a long isoform were detected after separation by capillary electrophoresis (Additional file 7: Figure S5C). e The graph represents the ratio of the relative abundance of the short isoform/long isoform in each experimental condition presented in (d) $(n=4, G M R$-Gal4 > UAS-TDP-43_TDPBR: $p=0.038$, GMR > TDP-43_TDPBR, UY5237: $p=0.017)$

We next asked whether CG42724 expression could affect the nucleocytoplasmic export of TDP-43 mRNAs. We performed cell fractionation (Additional file 8: Figure S6), and extracted total RNAs from nuclear and cytoplasmic fractions. Quantification of TDP-43 steadystate mRNA levels was achieved again by RT-QMPSF, using the F1/R1 and F2/R2 primers (Additional file 3: Table S1 and Additional file 7: Figure S5A). If CG42724 
expression modulates TDP-43 mRNA nucleocytoplasmic export, we expect to have different TDP-43_TDPBR, UY5237 / TDP-43_TDPBR ratios in the nuclear and the cytoplasmic compartments. However, we detected similar ratio in both compartments $(p=0.992)$ (Fig. $5 b)$, indicating that CG42724 expression did not modulate TDP-43 mRNA nucleocytoplasmic export.

We also examined whether the regulation of TDP-43 production by CG42724 occured via changes in alternative splicing events and/or differential usage of polyadenylation sites, performing 3' Rapid Amplification of cDNA Ends (RACE) experiments. PCR products were amplified using a human TDP-43-specific primer (F3, Additional file 7: Figure S5A and Additional file 3: Table S1) and an oligo-dT adapter primer. Agarose gel electrophoresis revealed, as previously described in [55], that TDP-43_TDPBR transgenic flies displayed a complex pattern of 3 ' RACE PCR amplification (Fig. 5c), with a $\sim 1.2 \mathrm{~kb}$ predominant band and lower migrating species. Co-expression of CG42724 resulted in a qualitative distinct pattern. Two main bands were now observed: $\mathrm{a} \sim 1.2 \mathrm{~kb}$ fragment (long isoform) and a smaller one of $\sim 800 \mathrm{bp}$ (short isoform). The sequencing of these two major bands revealed that they corresponded to alternative transcripts of different sizes resulting from differential usage of polyadenylation sites. Note that we failed to characterize the intermediate band by sequencing (asterisk, Fig. 5c). These species could correspond to heteroduplexes. To quantify the relative abundance of these spliced isoforms, we combined 3' RACE PCR amplification with QMPSF technology. In accordance with what we observed on agarose gel (Fig. 5c), we detected three fluorescent peaks corresponding to the expected amplicon sizes (short isoform: $\sim 840 \mathrm{bp}$, intermediates species: $\sim 1000 \mathrm{bp}$, long isoform: 1225 bp) (Additional file 7: Figure S5C). Accurate quantification of the relative amount of spliced isoforms showed that CG42724 expression resulted in an increased relative amount of the short isoform (from 10.71 $+/-1.7 \%$ to $28.26+/-5.17 \%, n=6, p=0.0177$ ), with a concomitant decrease of the long isoform (from $83.08+1-$ $1.32 \%$ to $67.47+/-4.79 \%, \mathrm{n}=6, p=0.0212$ ) (Fig. 5d, upper 2D-pies). Altogether, these data revealed that CG42724 expression affected qualitatively and quantitatively the TDP-43_TDPBR mRNA transcripts pattern.

Because alternative transcripts could display distinct nucleocytoplasmic export efficiency, we then achieved 3' RACE PCR amplification combined with QMPSF experiments after nucleocytoplasmic fractionation. If both TDP-43 mRNA isoforms were similarly distributed between the nuclear and cytoplasmic fractions, we would expect similar short/long (S/L) isoforms ratios of TDP-43 mRNA levels, whatever the experiments were performed using total mRNA or mRNA extracted from the cytoplasmic compartment. Quantification of the relative abundance of splice isoforms showed that the S/L ratio in the cytoplasmic compartment was significantly higher compared to that quantified in total mRNA (GMR> TDP-43_TDPBR flies: $\sim 2.7$ fold-change, $G M R>$ TDP-43_TDPBR, UY5237: 3.3 fold-change) (Fig. 5d, lower 2D-pies, E), demonstrating that short TDP-43 mRNA isoforms were more prone to be exported to the cytoplasm than long isoforms.

Thus, in our experimental system, we found that CG42724 overexpression promotes the production of transcripts including TDPBR sensor region and ending at the pA1 polyadenylation site, isoforms that can be efficiently released into the cytoplasm.

\section{Human TCERG 1 controls TDP-43 production in mammalian cells}

To validate these findings identified in Drosophila in mammalian cells, we first developed two hybrid constructs containing a GFP::TDP-43 reporter gene fused (GFP::TDP-43_TDPBR) or not (GFP::TDP-43) to the $T D P B R$ region, and compared their expression in HEK293 cells. As expected, introduction of the TDPBR sequence into the reporter construct resulted in a significant $\sim 50 \%$ decrease $(p=0.0053)$ in the GFP::TDP-43 protein expression levels (Fig. 6a, b). Co-transfection of the GFP::TDP-43_TDPBR reporter construct with a construct encoding the human T7-tagged TCERG1 protein, resulted in a significant increase of TDP-43::GFP protein steady-state levels relative to control transfections $(p=$ 0.0278) (Fig. 6a, c). In contrast, no significant increase in GFP::TDP-43 production was detected in the context of the GFP::TDP-43 reporter construct $(p=0.6659)$. Together these results showed that the human TCERG1 protein can regulate TDP-43 protein production in mammalian cells, and that TCERG1-mediated regulation of TDP-43 production is also predominantly mediated by the TDPBR region.

\section{Discussion}

TDP-43 is a critical RNA-binding factor that has been shown to play a central role in RNA metabolism. Cell functions and survival depend on the strict control of TDP-43 protein levels. TDP-43 expression is tightly regulated through an autoregulatory negative feedback loop mediated by the binding of TDP-43 protein in a specific region of its mRNA 3'UTR called TDPBR $[5,6,8,42,54]$. The TDPBR sensor region includes low-affinity binding sites for TDP-43 and the polyadenylation site pA1, the most efficient polyadenylation site of the TDP-43 gene. In steady-state conditions, most TDP-43 production within cells comes from the transcript that uses the polyadenylation site pA1. Increase in TDP-43 nuclear levels results in an increased occupancy of the TDPBR that in turn suppresses usage of the pA1 site, resulting in elongation of transcripts beyond pA1. The elongated transcripts present 


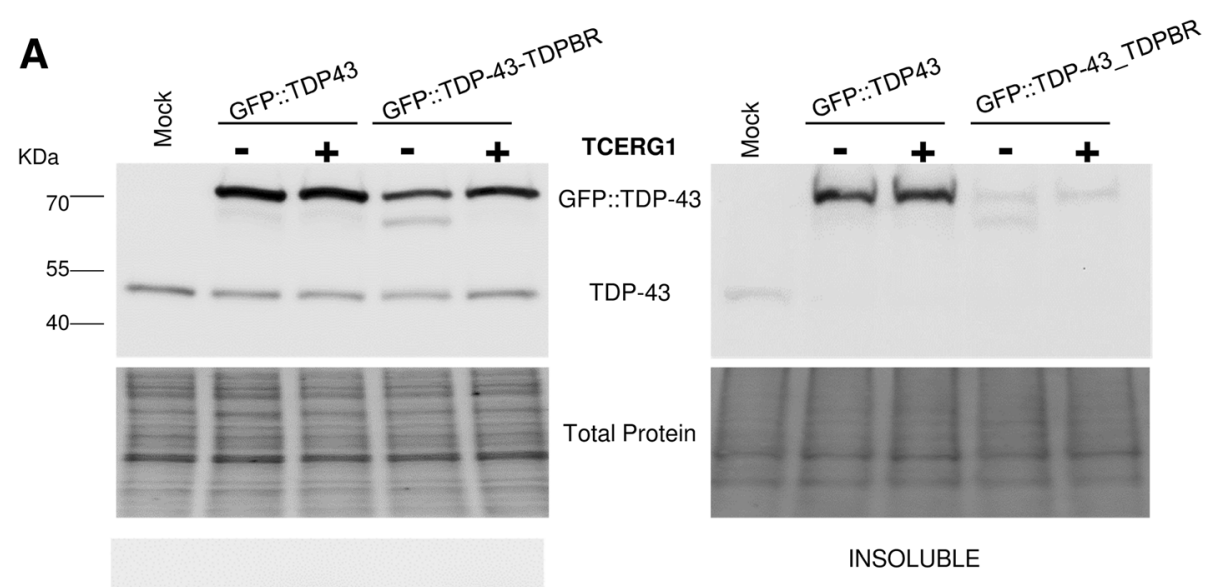

TCERG1
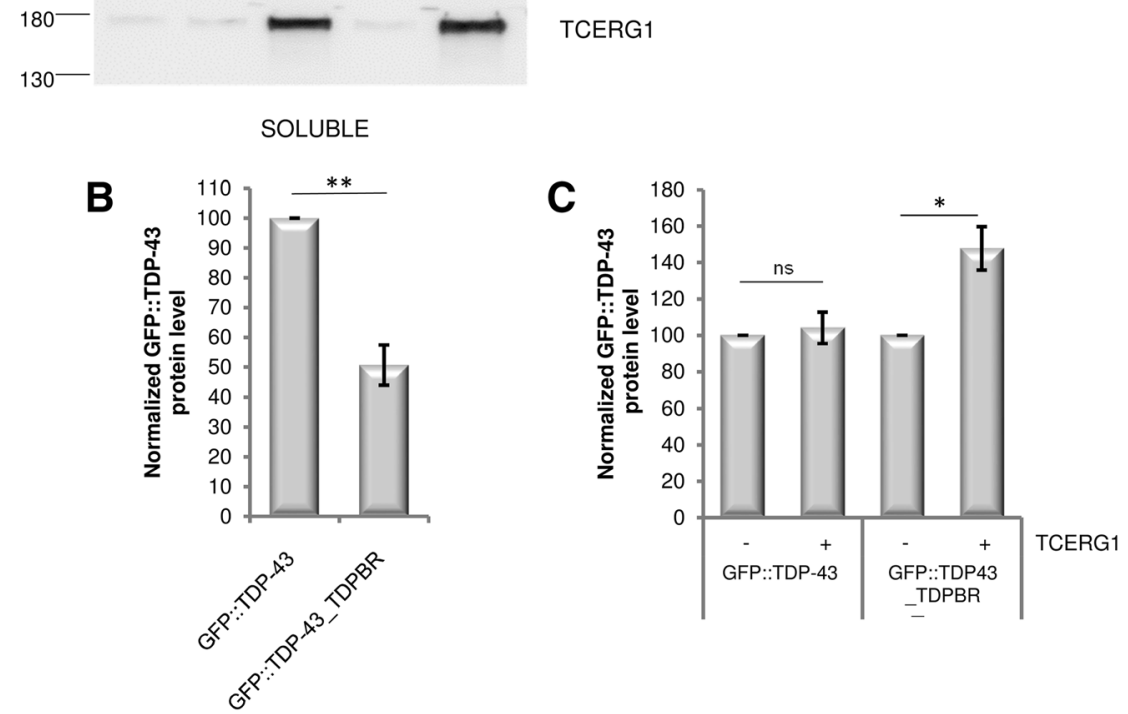

Fig. 6 Human TCERG1 influences TDP-43 production in HEK293T cells. a Western blot analysis of HEK293T cells with different combinations of GFP::TDP-43 and TCERG1 expression plasmids. Expression of both proteins were detected using anti-TDP-43 or anti-TCERG1 antibodies. Representative result from four independent experiments is presented. Proteins were sequentially extracted in RIPA (soluble) and Urea (insoluble) buffers. Total protein was used as the loading control. $\mathbf{b}, \mathbf{c}$ The normalized expression of the TDP-43 protein is reported in the graphs (mean \pm SEM). Protein levels were compared between both genotypes by using Student's t-test. ${ }^{* *}: p<0.001,{ }^{*}: p<0.05$

an acceptor site for normally silent intron that contains the TDPBR region and the pA1 sequence. The exclusion of this intron forces the system to use suboptimal polyadenylation sites. The mRNAs using these alternative polyadenylation sites show an increased incidence of alternative splicing, and are partially retained in the nucleus and/or degraded.

To identify genetic modulators of TDP-43 production in vivo, we used an autoregulatory TDP-43 Drosophila model previously developed and characterized by our group [55]. This Drosophila transgenic model is based on the expression of the human TDP-43 cDNA under the control of the TDPBR sensor region. This TDP-43_TDPBR Drosophila model recapitulates key features of the self-regulatory process of the steady-state levels of TDP-43 proteins described previously in mammalian and cellular models, namely alternative splicing events, differential usage of polyadenylation sites, nuclear retention of the transcripts, and a decrease in steady-state mRNA levels.

In this study, we report the identification of the CG42724 Drosophila gene as a genetic modulator of TDP-43 production in vivo. We showed that CG42724 overexpression caused a drastic increase of TDP-43 protein steady-state levels, whereas CG42724 down-regulation resulted in a decrease of TDP-43 accumulation. The study of the underlying molecular mechanisms allowed us to highlight that the CG42724 protein influences both qualitatively and quantitatively the TDP-43_TDPBR mRNA transcripts pattern. We found that CG42724 overexpression promotes the inclusion of the TDPBR sensor region as well as the production of transcripts ending at the pA1 polyadenylation, 
isoforms that can be efficiently released into the cytoplasm for protein translation. Of course, additional mechanisms could also be involved. Notably, we observed that TCERG1 expression resulted in a slight increase of TDP-43 mRNA steady-state level, which could also contribute to the increase in TDP-43 protein accumulation. Importantly, this effect predominantly depends on the presence of the $T D P B R$ region.

To date, very little is known about the Drosophila CG42724 protein. The protein is composed of 1123 residues and contains three WW domains at its $\mathrm{N}$-terminus followed by six FF domains at its $\mathrm{C}$-terminus. The CG42724 protein was detected in affinity-purified Drosophila spliceosome [31]. On the other hand, CG42724 was identified as an RS-domain containing protein in a genome-wide survey of RS domain proteins [13]. Interestingly, the RS-domains are frequently found in proteins involved in pre-mRNA splicing.

The CG42724 gene encodes a homolog of the human TCERG1 (Transcription elongation regulator 1) gene. The CG42724 and TCERG1 proteins share 35\% sequence identity and $48 \%$ sequence similarity. The highest homology is observed in the WW and FF domains. Importantly, our data suggest a significant degree of functional conservation between flies and mammals regarding the regulation of TDP-43 production. Indeed, we showed that similarly to CG42724, human TCERG1 overexpression also caused an increase of TDP-43 protein steady-state levels in mammalian cells.

TCERG1, previously named CA150, is a highly conserved human nuclear protein, localized at the interface of nuclear speckles and presumed nearby transcription sites $[59,60]$. TCERG1 was originally identified as a component of an active cellular fraction that supported Tat activated transcription from the HIV-LTR $[67,68]$. Consistent with a role in elongation [21], TCERG1 is found associated with elongation factors and RNA Polymerase II (RNAPII) holoenzyme [16, 30, 68]. Accumulating evidence also implicates TCERG1 in pre-RNA splicing regulation. TCERG1 interacts with splicing factors $[30,43]$ and has been identified in highly purified spliceosomes in multiple studies [25, 43, 45, 50, 57]. TCERG1 can affect pre-mRNA splicing of several splicing reporters $[43,48,53,60]$, and of putative cellular targets identified by microarray analysis following TCERG1 knockdown [49, 53]. Based on these data, TCERG1 has been suggested to couple the transcribing RNAPII with spliceosome complexes to regulate co-transcriptional splicing events, a hypothesis that was supported by the demonstration that TCERG1 regulates the alternative splicing of the Bclx gene through the modulation the RNAPII transcription rate [48].

Interestingly, TCERG1 and TDP-43 proteins have been linked to common aspects of mRNA life cycle, namely transcription, pre-mRNA alternative splicing and polyadenylation site selection. Uncovering the mechanism of action of TCERG1 on TDP-43 production is complicated by their multifaceted functions, but also by the fact that RNAPII transcription, alternative splicing and alternative polyadenylation can be influenced reciprocally. All these processes are tightly coupled and coordinated.

We showed in this study that these processes of regulation predominantly depend on the presence of the $T D P B R$ region. We demonstrated previously that the negative regulatory activity of the TDPBR region is specifically dependent on TDP-43 expression [55], suggesting that the TDP- 43 protein itself could be implicated in the TCERG1-mediated regulation of TDP-43 production. One hypothesis would be that TCERG1 protein interferes with the binding of TDP-43 on the TDPBR region, possibly by competition through binding the same mRNA site. Indeed, even if TCERG1 has not been described as an RNA-binding protein, it has been shown that the protein associates in vitro with the $B c l-x$ pre-mRNA [48]. Alternatively, it could act by "sequestration" of TDP-43 out of the transcripts. However, to our knowledge, proteomic studies performed in several cell lines did not identify TCERG1 as a potential TDP-43 interacting partner $[11,27,63,75]$. In contrast, they share several common interacting partners, such as the SRSF1, SRSF3, SRSF7, and SF3B splicing factors.

As a component of the splicing machinery, TCERG1 could also modulate the spliceosome assembly and activity. Consistent with this possibility, it has been shown that spliceosome assembly across the 3'UTR region induced by TDP-43 is a key event in the reduction of the amount of TDP-43 [8]. The 3'UTR intron 7 recognition by the splicing machinery somehow marks the bulk of the transcript for nuclear retention and degradation. Therefore, TCERG1 overexpression could alter the recognition of the intron 7 splicing sites, and consequently favor the recognition of pA1.

Otherwise, it has been shown that TDP-43 overexpression causes a rise in RNAPII density from the TDPBR sequence to the downstream region [5]. Such a pausing of RNAPII could influence polyA site usage [28] and the more efficient recognition of weaker splice sites $[15,40]$. Thus, the pausing of RNAPII in the TDPBR region could interfere with the recognition of pA1, forcing the use of suboptimal polyadenylation sites. As mentioned above, TCERG1 modulates the rate of RNAPII transcription by increasing its elongation rate [21]. Therefore, in our experimental model, TCERG1 overexpression could release paused polymerase, and therefore allow the use of pA1 and the production of transcripts that can be transported into the cytoplasm for protein synthesis. It is also possible that TCERG1 works at the interface of RNAPII and the splicing machinery. Indeed, as mentioned above, 
TCERG1 can regulate alternative splicing events by modulating the rate of RNAPII transcription [48]. Thus, although our data are fully consistent with the known functions of the human protein TCERG1, they do not discriminate between several potential mechanisms. Of course, these mechanisms are non-exclusive, it is possible for all to work together.

Transcriptomic studies showed that TCERG1 is widely and highly expressed in the brain (cerebral cortex, hippocampus, lateral ventricle, and cerebellum). Interestingly, TCERG1 has already been implicated in the pathogenesis of the neurodegenerative disorder Huntington's disease (HD). TCERG1 interacts with the huntingtin (HTT) protein and has been associated with the morphological deposits related to the disease [34]. TCERG1 could play a neuroprotective role in HD because its overexpression rescues neuronal cell death due to mutant HTT neurotoxicity [3]. TCERG1 has also been identified as a genetic modulator of Tau neurotoxicity in a genetic screen performed in our laboratory [10]. However, to date the molecular mechanisms underlying TCERG1-mediated neuronal effects remain largely unknown. A recent study showed that TCERG1 is required for normal neurite development in cultured cells, and suggested that abnormal regulation of the transcription and/or alternative splicing of TCERG1-specific targets may therefore play a role in the pathogenesis of TCERG1-associated neurological disorders [49].

\section{Conclusions}

To conclude, using a Drosophila model that recapitulates key features of the TDP-43 auto-regulatory feedback loop, we have identified TCERG1 as a modulator of TDP-43 production in vivo. Further studies will be necessary to unravel the exact mechanisms through which TCERG1 modulates TDP-43 production. Nevertheless, regardless of underlying mechanisms, our data suggest the possibility that targeting TCERG1 could be therapeutic in TDP-43 proteinopathies.

\section{Additional file}

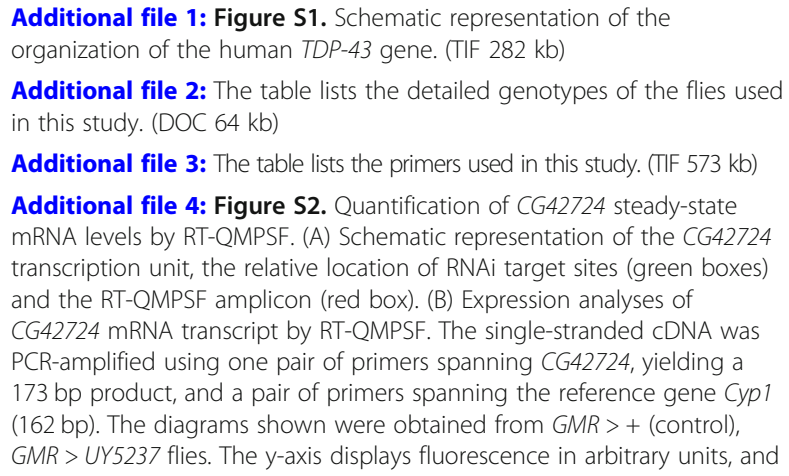

Additional file 2: The table lists the detailed genotypes of the flies used in this study. (DOC $64 \mathrm{~kb}$ )

Additional file 3: The table lists the primers used in this study. (TIF $573 \mathrm{~kb}$ )

Additional file 4: Figure S2. Quantification of CG42724 steady-state mRNA levels by RT-QMPSF. (A) Schematic representation of the CG42724 transcription unit, the relative location of RNAi target sites (green boxes) and the RT-QMPSF amplicon (red box). (B) Expression analyses of CG42724 mRNA transcript by RT-QMPSF. The single-stranded CDNA was PCR-amplified using one pair of primers spanning CG42724, yielding a $173 \mathrm{bp}$ product, and a pair of primers spanning the reference gene Cyp 1 (162 bp). The diagrams shown were obtained from GMR > + (control), GMR > UY5237 flies. The $y$-axis displays fluorescence in arbitrary units, and

the $x$-axis indicates the size in bp. The electropherogram of the GMR > + (blue) and GMR > UY5237 (green) flies were superimposed by adjusting the peaks obtained for the control amplicon to the same level. (TIF $456 \mathrm{~kb}$ )

Additional file 5: Figure S3. Light micrographs of new-born Drosophila adult eyes. Compared to control flies (GMR-Gal4 $>+$ ), expression of CG42724 (GMR-Gal4 > UY5237) or TDP-43_TDPBR (GMR-Gal4 > UAS-TDP43_TDPBR) alone triggered no structural defects. Similarly, flies coexpressing CG42724 and TDP-43_TDPBR have no external phenotype. (TIF 25334 kb)

Additional file 6: Figure S4. Homology TCERG1 and CG42724. Alignment of the human TCERG1 and Drosophila CG42724 proteins. TCERG1 and CG42724 share 35\% sequence identity and 48\% sequence similarity. The highest homology is observed in the WW domain (blue) and the FF domain (red). Alignment was performed using DRSC Integrative Ortholog Prediction Tool. (TIF 338 kb)

Additional file 7: Figure S5. Quantification of TDP-43 steady-state mRNA levels by RT-QMPSF. (A) Schematic representation of the TDP-43 transcription unit and the relative location of the RT-QMPSF amplicons. (B) Expression analyses of TDP-43 mRNA transcripts by RT-QMPSF. This assay is based on simultaneous PCR amplification of short fluorescent fragments in a single tube. The single-stranded CDNA was PCR-amplified using: TDP-43 $3^{\mathrm{F} 1 / \mathrm{R} 1}$ yielding a $115 \mathrm{bp}$ product, TDP-43 $3^{\mathrm{F} / \mathrm{R} 2}$ that yielded fragments of $132 \mathrm{bp}$ and CG42724 that produced an amplicon of $173 \mathrm{bp}$ (Additional file 1: Figure S1A). RpL13A (141 bp) and Cyp1 (162 bp) cDNAs were amplified as internal references. The number of cycles of amplification was determined by testing a range of cycle numbers in order to remain in the linear phase of the PCR. Fluorescent amplicons were separated on a genetic analyzer and the resulting fluorescent profiles were analyzed. The diagrams shown were obtained from GMR > + (control, blue), GMR $>$ TDP43_TDPBR (red) or GMR > TDP-43_TDPBR, UY5237 (green) flies. The y-axis displays fluorescence in arbitrary units, and the $x$-axis indicates the size in bp. The electropherograms were superimposed by adjusting the peaks obtained for the control amplicons to the same level. (C) TDP-43 amplicons were amplified using a TDP-43-specific primer (F3) and an oligo-dT adapter primer (AUAP). The diagrams shown were obtained from $G M R>+$ (control, blue), GMR > TDP-43_TDPBR (red) or GMR > TDP-43_TDPBR, UY5237 (green) flies. Cyp 1 cDNAs was amplified as internal reference. The electropherograms were superimposed by adjusting the peaks obtained for the control amplicons to the same level. Note that the "mis-alignement » of the longest pics is due to the imprecise sizing of the fragment $>1 \mathrm{~kb}$. (TIF $1151 \mathrm{~kb}$ )

Additional file 8: Figure S6. Purity of subcellular fractions. Cytoplasmic/ nuclear fractionation was performed on GMR > + (control), GMR-Gal4 > UASTDP-43_TDPBR or GMR-Gal4 > UAS-TDP-43_TDPBR, UY5237 transgenic flies. Nuclear (N) and cytoplasmic (C) fractions were qualified by performing Western blot experiments. Results shown are representative of 3 independent biological replicates. $\beta$-tubulin was used as a cytosolic marker, while histone $\mathrm{H} 3$ was used as a nuclear marker. Total protein was used as the loading control by Stain-free technology. (TIF 683 kb)

\section{Acknowledgments}

We thank Françoise Charbonnier and Anne Rovelet-Lecrux for technical assistance in RT-QMPSF experiments. We thank the Bloomington Drosophila stock center for providing fly stocks. This work was supported by a grant from the European Union and the Région Normandy. Europe gets involved in Normandy through the European Regional Development Fund (ERDF). MP is a PhD fellow of the French Ministry of Higher Education and Research.

\section{Funding}

This work was supported by a grant from the European Union and the Région Normandy. Europe gets involved in Normandy through the European Regional Development Fund (ERDF). MP is a PhD fellow of the French Ministry of Higher Education and Research.

Availability of data and materials Not applicable. 


\section{Authors' contributions}

MP, SP, LM and ML designed the study, carried out the experiment and analyzed the results. ML, CS, DC and TF supervised the project. ML wrote the manuscript with support from MP, LM, SP and CS Funding were obtained by ML, DC, CS and TF. All authors read and approved the final manuscript.

\section{Ethics approval and consent to participate}

Not applicable.

\section{Consent for publication}

Not applicable

\section{Competing interests}

The authors declare that they have no competing interests.

\section{Publisher's Note}

Springer Nature remains neutral with regard to jurisdictional claims in published maps and institutional affiliations.

\section{Author details}

${ }^{1}$ Normandie University, UNIROUEN, Inserm, U1245, IRIB, Rouen, France. ${ }^{2}$ Department of Molecular Biology, Institute of Parasitology and Biomedicine "López Neyra" (IPBLN-CSIC), PTS, 18016 Granada, Spain. ${ }^{3}$ Department of Genetics, Rouen University Hospital, Rouen, France. ${ }^{4}$ Centre Hospitalier du Rouvray, Sotteville-Lès-Rouen, France.

Received: 26 October 2018 Accepted: 23 November 2018 Published online: 12 December 2018

\section{References}

1. Amador-Ortiz C, Lin W-L, Ahmed Z, Personett D, Davies P, Duara R, GraffRadford NR, Hutton ML, Dickson DW (2007) TDP-43 immunoreactivity in hippocampal sclerosis and Alzheimer's disease. Ann Neurol 61:435-445. https://doi.org/10.1002/ana.21154

2. $\quad$ Arai T, Hasegawa M, Akiyama H, Ikeda K, Nonaka T, Mori H, Mann D, Tsuchiya K, Yoshida M, Hashizume Y, Oda T (2006) TDP-43 is a component of ubiquitin-positive tau-negative inclusions in frontotemporal lobar degeneration and amyotrophic lateral sclerosis. Biochem Biophys Res Commun 351:602-611. https://doi.org/10.1016/j.bbrc.2006.10.093.

3. Arango M, Holbert S, Zala D, Brouillet E, Pearson J, Régulier E, Thakur AK, Aebischer P, Wetzel R, Déglon N, Néri C (2006) CA150 expression delays striatal cell death in overexpression and knock-in conditions for mutant huntingtin neurotoxicity. J Neurosci 26:4649-4659. https://doi.org/10.1523/ JNEUROSCI.5409-05.2006

4. Austin JA, Wright GSA, Watanabe S, Grossmann JG, Antonyuk SV, Yamanaka K, Hasnain SS (2014) Disease causing mutants of TDP-43 nucleic acid binding domains are resistant to aggregation and have increased stability and half-life. Proc Natl Acad Sci U S A 111:4309-4314. https://doi.org/10. 1073/pnas.1317317111

5. Avendaño-Vázquez SE, Dhir A, Bembich S, Buratti E, Proudfoot N, Baralle FE (2012) Autoregulation of TDP-43 mRNA levels involves interplay between transcription, splicing, and alternative polyA site selection. Genes Dev 26: 1679-1684.

6. Ayala YM, De Conti L, Avendaño-Vázquez SE, Dhir A, Romano M, D'Ambrogio A, Tollervey J, Ule J, Baralle M, Buratti E, Baralle FE (2011) TDP43 regulates its $\mathrm{mRNA}$ levels through a negative feedback loop. EMBO J 30: 277-288.

7. Ayala YM, Zago P, D'Ambrogio A, Xu Y-F, Petrucelli L, Buratti E, Baralle FE (2008) Structural determinants of the cellular localization and shuttling of TDP-43. J Cell Sci 121:3778-3785.

8. Bembich S, Herzog JS, De Conti L, Stuani C, Avendaño-Vázquez SE, Buratti E, Baralle M, Baralle FE (2014) Predominance of spliceosomal complex formation over polyadenylation site selection in TDP-43 autoregulation. Nucleic Acids Res 42:3362-3371.

9. Bilican B, Serio A, Barmada SJ, Nishimura AL, Sullivan GJ, Carrasco M, Phatnani HP, Puddifoot CA, Story D, Fletcher J, Park I-H, Friedman BA, Daley GQ, Wyllie DJA, Hardingham GE, Wilmut I, Finkbeiner S, Maniatis T, Shaw CE, Chandran S (2012) Mutant induced pluripotent stem cell lines recapitulate aspects of TDP-43 proteinopathies and reveal cell-specific vulnerability. Proc Natl Acad Sci U S A 109:5803-5808. https://doi.org/10.1073/pnas. 1202922109
10. Blard O, Feuillette S, Bou J, Chaumette B, Frébourg T, Campion D, Lecourtois M (2007) Cytoskeleton proteins are modulators of mutant tau-induced neurodegeneration in Drosophila. Hum Mol Genet 16:555-566.

11. Blokhuis AM, Koppers M, Groen EJN, van den Heuvel DMA, Dini Modigliani S, Anink JJ, Fumoto K, van Diggelen F, Snelting A, Sodaar P, Verheijen BM, Demmers JAA, Veldink JH, Aronica E, Bozzoni I, den Hertog J, van den Berg LH, Pasterkamp RJ (2016) Comparative interactomics analysis of different ALS-associated proteins identifies converging molecular pathways. Acta Neuropathol (Berl) 132:175-196. https://doi.org/10.1007/s00401-016-1575-8.

12. Borroni B, Bonvicini C, Alberici A, Buratti E, Agosti C, Archetti S, Papetti A, Stuani C, Di Luca M, Gennarelli M, Padovani A (2009) Mutation within TARDBP leads to frontotemporal dementia without motor neuron disease. Hum Mutat 30:E974-E983. https://doi.org/10.1002/humu.21100.

13. Boucher L, Ouzounis CA, Enright AJ, Blencowe BJ (2001) A genome-wide survey of RS domain proteins. RNA N Y N 7:1693-1701.

14. Cairns NJ, Neumann M, Bigio EH, Holm IE, Troost D, Hatanpaa KJ, Foong C, White CL, Schneider JA, Kretzschmar HA, Carter D, Taylor-Reinwald L, Paulsmeyer K, Strider J, Gitcho M, Goate AM, Morris JC, Mishra M, Kwong LK, Stieber A, Xu Y, Forman MS, Trojanowski JQ, Lee VM-Y, Mackenzie IRA (2007) TDP-43 in familial and sporadic frontotemporal lobar degeneration with ubiquitin inclusions. Am J Pathol 171:227-240. https://doi.org/10.2353/ ajpath.2007.070182.

15. Carrillo Oesterreich F, Bieberstein N, Neugebauer KM (2011) Pause locally, splice globally. Trends Cell Biol 21:328-335. https://doi.org/10.1016/j.tcb. 2011.03.002.

16. Carty SM, Goldstrohm AC, Suñé C, Garcia-Blanco MA, Greenleaf AL (2000) Protein-interaction modules that organize nuclear function: FF domains of CA150 bind the phosphoCTD of RNA polymerase II. Proc Natl Acad Sci U S A 97:9015-9020. https://doi.org/10.1073/pnas.160266597.

17. Casci I, Pandey UB (2015) A fruitful endeavor: modeling ALS in the fruit fly. Brain Res 1607:47-74. https://doi.org/10.1016/j.brainres.2014.09.064.

18. Chanson J-B, Echaniz-Laguna A, Vogel T, Mohr M, Benoilid A, Kaltenbach G, Kiesmann M (2010) TDP43-positive intraneuronal inclusions in a patient with motor neuron disease and Parkinson's disease. Neurodegener Dis 7:260264. https://doi.org/10.1159/000273591.

19. Chen $Y$, Yang $M$, Deng J, Chen $X, Y e ~ Y$, Zhu L, Liu J, Ye H, Shen $Y$, Li Y, Rao EJ, Fushimi K, Zhou X, Bigio EH, Mesulam M, Xu Q, Wu JY (2011) Expression of human FUS protein in Drosophila leads to progressive neurodegeneration. Protein Cell 2:477-486. https://doi.org/10.1007/s13238011-1065-7.

20. Chen-Plotkin AS, Geser F, Plotkin JB, Clark CM, Kwong LK, Yuan W, Grossman M, Van Deerlin VM, Trojanowski JQ, Lee VM-Y (2008) Variations in the progranulin gene affect global gene expression in frontotemporal lobar degeneration. Hum Mol Genet 17:1349-1362. https://doi.org/10.1093/hmg/ ddn023.

21. Coiras M, Montes M, Montanuy I, López-Huertas MR, Mateos E, Le Sommer C, Garcia-Blanco MA, Hernández-Munain C, Alcamí J, Suñé C (2013) Transcription elongation regulator 1 (TCERG1) regulates competent RNA polymerase II-mediated elongation of HIV-1 transcription and facilitates efficient viral replication. Retrovirology 10:124. https://doi.org/10.1186/17424690-10-124.

22. Coyne AN, Zaepfel BL, Zarnescu DC (2017) Failure to deliver and translatenew insights into RNA dysregulation in ALS. Front Cell Neurosci 11:243. https://doi.org/10.3389/fncel.2017.00243.

23. Davidson Y, Amin H, Kelley T, Shi J, Tian J, Kumaran R, Lashley T, Lees AJ, DuPlessis D, Neary D, Snowden J, Akiyama H, Arai T, Hasegawa M, Bandopadhyay R, Sikkink S, Pickering-Brown S, Mann DMA (2009) TDP-43 in ubiquitinated inclusions in the inferior olives in frontotemporal lobar degeneration and in other neurodegenerative diseases: a degenerative process distinct from normal ageing. Acta Neuropathol (Berl) 118:359-369. https://doi.org/10.1007/s00401-009-0526-z.

24. Davidson Y, Kelley T, Mackenzie IRA, Pickering-Brown S, Du Plessis D, Neary D, Snowden JS, Mann DMA (2007) Ubiquitinated pathological lesions in frontotemporal lobar degeneration contain the TAR DNA-binding protein, TDP-43. Acta Neuropathol (Berl) 113:521-533. https://doi.org/10.1007/ s00401-006-0189-y.

25. Deckert J, Hartmuth K, Boehringer D, Behzadnia N, Will CL, Kastner B, Stark H, Urlaub H, Lührmann R (2006) Protein composition and electron microscopy structure of affinity-purified human spliceosomal B complexes isolated under physiological conditions. Mol Cell Biol 26:5528-5543. https:// doi.org/10.1128/MCB.00582-06. 
26. Faber PW, Barnes GT, Srinidhi J, Chen J, Gusella JF, MacDonald ME (1998) Huntingtin interacts with a family of WW domain proteins. Hum Mol Genet 7:1463-1474.

27. Freibaum BD, Chitta RK, High AA, Taylor JP (2010) Global analysis of TDP-43 interacting proteins reveals strong association with RNA splicing and translation machinery. J Proteome Res 9:1104-1120.

28. Fusby B, Kim S, Erickson B, Kim H, Peterson ML, Bentley DL (2016) Coordination of RNA polymerase II pausing and $3^{\prime}$ end processing factor recruitment with alternative polyadenylation. Mol Cell Biol 36:295-303. https://doi.org/10.1128/MCB.00898-15.

29. Gitcho MA, Bigio EH, Mishra M, Johnson N, Weintraub S, Mesulam M, Rademakers R, Chakraverty S, Cruchaga C, Morris JC, Goate AM, Cairns NJ (2009) TARDBP 3'-UTR variant in autopsy-confirmed frontotemporal lobar degeneration with TDP-43 proteinopathy. Acta Neuropathol (Berl) 118:633645. https://doi.org/10.1007/s00401-009-0571-7.

30. Goldstrohm AC, Albrecht TR, Suñé C, Bedford MT, Garcia-Blanco MA (2001) The transcription elongation factor CA150 interacts with RNA polymerase II and the pre-mRNA splicing factor SF1. Mol Cell Biol 21:7617-7628. https:// doi.org/10.1128/MCB.21.22.7617-7628.2001.

31. Herold N, Will CL, Wolf E, Kastner B, Urlaub H, Lührmann R (2009) Conservation of the protein composition and electron microscopy structure of Drosophila melanogaster and human spliceosomal complexes. Mol Cell Biol 29:281-301.

32. Hewamadduma CAA, Grierson AJ, Ma TP, Pan L, Moens CB, Ingham PW, Ramesh T, Shaw PJ (2013) Tardbpl splicing rescues motor neuron and axonal development in a mutant tardbp zebrafish. Hum Mol Genet 22: 2376-2386.

33. Higuchi R, Krummel B, Saiki RK (1988) A general method of in vitro preparation and specific mutagenesis of DNA fragments: study of protein and DNA interactions. Nucleic Acids Res 16:7351-7367.

34. Holbert S, Denghien I, Kiechle T, Rosenblatt A, Wellington C, Hayden MR, Margolis RL, Ross CA, Dausset J, Ferrante RJ, Néri C (2001) The Gln-ala repeat transcriptional activator CA150 interacts with huntingtin: neuropathologic and genetic evidence for a role in Huntington's disease pathogenesis. Proc Natl Acad Sci U S A 98:1811-1816. https://doi.org/10. 1073/pnas.041566798.

35. Iguchi Y, Eid L, Parent M, Soucy G, Bareil C, Riku Y, Kawai K, Takagi S, Yoshida M, Katsuno M, Sobue G, Julien J-P (2016) Exosome secretion is a key pathway for clearance of pathological TDP-43. Brain J Neurol 139:31873201. https://doi.org/10.1093/brain/aww237.

36. Josephs KA, Murray ME, Whitwell $J$, Parisi JE, Petrucelli L, Jack CR, Petersen RC, Dickson DW (2014) Staging TDP-43 pathology in Alzheimer's disease. Acta Neuropathol (Berl) 127:441-450. https://doi.org/10.1007/s00401-0131211-9.

37. Kabashi E, Valdmanis PN, Dion P, Spiegelman D, McConkey BJ, Vande Velde C, Bouchard J-P, Lacomblez L, Pochigaeva K, Salachas F, Pradat P-F, Camu W, Meininger V, Dupre N, Rouleau GA (2008) TARDBP mutations in individuals with sporadic and familial amyotrophic lateral sclerosis. Nat Genet 40:572-574. https://doi.org/10.1038/ng.132.

38. Kapeli K, Martinez FJ, Yeo GW (2017) Genetic mutations in RNA-binding proteins and their roles in ALS. Hum Genet. https://doi.org/10.1007/s00439017-1830-7.

39. Kasai T, Tokuda T, Ishigami N, Sasayama H, Foulds P, Mitchell DJ, Mann DMA, Allsop D, Nakagawa M (2009) Increased TDP-43 protein in cerebrospinal fluid of patients with amyotrophic lateral sclerosis. Acta Neuropathol (Berl) 117:55-62. https://doi.org/10.1007/s00401-008-0456-1.

40. Kornblihtt AR (2007) Coupling transcription and alternative splicing. Adv Exp Med Biol 623:175-189.

41. Kovacs GG, Murrell JR, Horvath S, Haraszti L, Majtenyi K, Molnar MJ, Budka H, Ghetti B, Spina S (2009) TARDBP variation associated with frontotemporal dementia, supranuclear gaze palsy, and chorea. Mov Disord 24:1843-1847. https://doi.org/10.1002/mds.22697.

42. Koyama A, Sugai A, Kato T, Ishihara T, Shiga A, Toyoshima Y, Koyama M, Konno T, Hirokawa S, Yokoseki A, Nishizawa M, Kakita A, Takahashi H, Onodera O (2016) Increased cytoplasmic TARDBP mRNA in affected spinal motor neurons in ALS caused by abnormal autoregulation of TDP-43. Nucleic Acids Res 44:5820-5836.

43. Lin K-T, Lu R-M, Tarn W-Y (2004) The WW domain-containing proteins interact with the early spliceosome and participate in pre-mRNA splicing in vivo. Mol Cell Biol 24:9176-9185. https://doi.org/10.1128/MCB.24.20.91769185.2004.
44. Liu Y-C, Chiang P-M, Tsai K-J (2013) Disease animal models of TDP-43 proteinopathy and their pre-clinical applications. Int J Mol Sci 14:2007920111.

45. Makarov EM, Makarova OV, Urlaub H, Gentzel M, Will CL, Wilm M, Lührmann $R$ (2002) Small nuclear ribonucleoprotein remodeling during catalytic activation of the spliceosome. Science 298:2205-2208. https://doi.org/10. 1126/science.1077783.

46. Mishra M, Paunesku T, Woloschak GE, Siddique T, Zhu L, Lin S, Greco K, Bigio EH (2007) Gene expression analysis of frontotemporal lobar degeneration of the motor neuron disease type with ubiquitinated inclusions. Acta Neuropathol (Berl) 114:81-94. https://doi.org/10.1007/ s00401-007-0240-7.

47. Monnier V, Girardot F, Cheret C, Andres O (2000) Tricoire H (2002) modulation of oxidative stress resistance in Drosophila melanogaster by gene overexpression. Genes 34:76-79. https://doi.org/10.1002/gene.10130.

48. Montes M, Cloutier A, Sánchez-Hernández N, Michelle L, Lemieux B, Blanchette M, Hernández-Munain C, Chabot B, Suñé C (2012) TCERG1 regulates alternative splicing of the $\mathrm{BCl}-\mathrm{x}$ gene by modulating the rate of RNA polymerase II transcription. Mol Cell Biol 32:751-762. https://doi.org/10. 1128/MCB.06255-11.

49. Muñoz-Cobo JP, Sánchez-Hernández N, Gutiérrez S, El Yousfi Y, Montes M, Gallego C, Hernández-Munain C, Suñé C (2017) Transcriptional elongation regulator 1 affects transcription and splicing of genes associated with cellular morphology and cytoskeleton dynamics and is required for neurite outgrowth in neuroblastoma cells and primary neuronal cultures. Mol Neurobiol 54:7808-7823. https://doi.org/10.1007/s12035-016-0284-6.

50. Neubauer G, King A, Rappsilber J, Calvio C, Watson M, Ajuh P, Sleeman J, Lamond A, Mann M (1998) Mass spectrometry and EST-database searching allows characterization of the multi-protein spliceosome complex. Nat Genet 20:46-50. https://doi.org/10.1038/1700.

51. Neumann M, Sampathu DM, Kwong LK, Truax AC, Micsenyi MC, Chou TT, Bruce J, Schuck T, Grossman M, Clark CM, McCluskey LF, Miller BL, Masliah E, Mackenzie IR, Feldman H, Feiden W, Kretzschmar HA, Trojanowski JQ, Lee VM-Y (2006) Ubiquitinated TDP-43 in frontotemporal lobar degeneration and amyotrophic lateral sclerosis. Science 314:130-133. https://doi.org/10. 1126/science.1134108.

52. Ou SH, Wu F, Harrich D, García-Martínez LF, Gaynor RB (1995) Cloning and characterization of a novel cellular protein, TDP-43, that binds to human immunodeficiency virus type 1 TAR DNA sequence motifs. J Virol 69:35843596.

53. Pearson JL, Robinson TJ, Muñoz MJ, Kornblihtt AR, Garcia-Blanco MA (2008) Identification of the cellular targets of the transcription factor TCERG1 reveals a prevalent role in mRNA processing. J Biol Chem 283:7949-7961. https://doi.org/10.1074/jbc.M709402200.

54. Polymenidou M, Lagier-Tourenne C, Hutt KR, Huelga SC, Moran J, Liang TY, Ling S-C, Sun E, Wancewicz E, Mazur C, Kordasiewicz H, Sedaghat $Y$, Donohue JP, Shiue L, Bennett CF, Yeo GW, Cleveland DW (2011) Long premRNA depletion and RNA missplicing contribute to neuronal vulnerability from loss of TDP-43. Nat Neurosci 14:459-468.

55. Pons M, Miguel L, Miel C, Avequin T, Juge F, Frebourg T, Campion D, Lecourtois M (2017) Splicing factors act as genetic modulators of TDP-43 production in a new autoregulatory TDP-43 Drosophila model. Hum Mol Genet 26:3396-3408. https://doi.org/10.1093/hmg/ddx229.

56. Rabin SJ, Kim JMH, Baughn M, Libby RT, Kim YJ, Fan Y, Libby RT, La Spada A, Stone B, Ravits J (2010) Sporadic ALS has compartment-specific aberrant exon splicing and altered cell-matrix adhesion biology. Hum Mol Genet 19: 313-328. https://doi.org/10.1093/hmg/ddp498.

57. Rappsilber J, Ryder U, Lamond Al, Mann M (2002) Large-scale proteomic analysis of the human spliceosome. Genome Res 12:1231-1245. https://doi. org/10.1101/gr.473902.

58. Rivero-Gutiérrez B, Anzola A, Martínez-Augustin O, de Medina FS (2014) Stain-free detection as loading control alternative to Ponceau and housekeeping protein immunodetection in Western blotting. Anal Biochem 467:1-3.

59. Sánchez-Alvarez M, Goldstrohm AC, Garcia-Blanco MA, Suñé C (2006) Human transcription elongation factor CA150 localizes to splicing factor-rich nuclear speckles and assembles transcription and splicing components into complexes through its amino and carboxyl regions. Mol Cell Biol 26:49985014. https://doi.org/10.1128/MCB.01991-05.

60. Sánchez-Hernández N, Ruiz L, Sánchez-Álvarez M, Montes M, Macias MJ, Hernández-Munain C, Suñé C (2012) The FF4 and FF5 domains of 
transcription elongation regulator 1 (TCERG1) target proteins to the periphery of speckles. J Biol Chem 287:17789-17800. https://doi.org/10. 1074/jbc.M111.304782.

61. Schmid B, Hruscha A, Hogl S, Banzhaf-Strathmann J, Strecker K, van der Zee J, Teucke M, Eimer S, Hegermann J, Kittelmann M, Kremmer E, Cruts M, Solchenberger B, Hasenkamp L, van Bebber F, Van Broeckhoven C, Edbauer D, Lichtenthaler SF, Haass C (2013) Loss of ALS-associated TDP-43 in zebrafish causes muscle degeneration, vascular dysfunction, and reduced motor neuron axon outgrowth. Proc Natl Acad Sci U S A 110:4986-4991.

62. Schwab C, Arai T, Hasegawa M, Yu S, McGeer PL (2008) Colocalization of transactivation-responsive DNA-binding protein 43 and huntingtin in inclusions of Huntington disease. J Neuropathol Exp Neurol 67:1159-1165. https://doi.org/10.1097/NEN.0b013e31818e8951.

63. Sephton CF, Cenik C, Kucukural A, Dammer EB, Cenik B, Han Y, Dewey CM, Roth FP, Herz J, Peng J, Moore MJ, Yu G (2011) Identification of neuronal RNA targets of TDP-43-containing ribonucleoprotein complexes. J Biol Chem 286:1204-1215.

64. Serio A, Bilican B, Barmada SJ, Ando DM, Zhao C, Siller R, Burr K, Haghi G, Story D, Nishimura AL, Carrasco MA, Phatnani HP, Shum C, Wilmut l, Maniatis T, Shaw CE, Finkbeiner S, Chandran S (2013) Astrocyte pathology and the absence of non-cell autonomy in an induced pluripotent stem cell model of TDP-43 proteinopathy. Proc Natl Acad Sci U S A 110:4697-4702. https://doi.org/10.1073/pnas.1300398110.

65. Sreedharan J, Blair IP, Tripathi VB, Hu X, Vance C, Rogelj B, Ackerley S, Durnall JC, Williams KL, Buratti E, Baralle F, de Belleroche J, Mitchell JD, Leigh PN, Al-Chalabi A, Miller CC, Nicholson G, Shaw CE (2008) TDP-43 mutations in familial and sporadic amyotrophic lateral sclerosis. Science 319 : 1668-1672. https://doi.org/10.1126/science.1154584.

66. Stribl C, Samara A, Trümbach D, Peis R, Neumann M, Fuchs H, Gailus-Durner V, Hrabě de Angelis M, Rathkolb B, Wolf E, Beckers J, Horsch M, Neff F, Kremmer E, Koob S, Reichert AS, Hans W, Rozman J, Klingenspor M, Aichler M, Walch AK, Becker L, Klopstock T, Glasl L, Hölter SM, Wurst W, Floss T (2014) Mitochondrial dysfunction and decrease in body weight of a transgenic knock-in mouse model for TDP-43. J Biol Chem 289:1076910784. https://doi.org/10.1074/jbc.M113.515940.

67. Suñé C, Garcia-Blanco MA (1999) Transcriptional cofactor CA150 regulates RNA polymerase II elongation in a TATA-box-dependent manner. Mol Cell Biol 19:4719-4728.

68. Suñé C, Hayashi T, Liu Y, Lane WS, Young RA, Garcia-Blanco MA (1997) CA150, a nuclear protein associated with the RNA polymerase II holoenzyme, is involved in tat-activated human immunodeficiency virus type 1 transcription. Mol Cell Biol 17:6029-6039.

69. Swarup V, Phaneuf D, Dupré N, Petri S, Strong M, Kriz J, Julien J-P (2011) Deregulation of TDP-43 in amyotrophic lateral sclerosis triggers nuclear factor KB-mediated pathogenic pathways. J Exp Med 208:2429-2447. https://doi.org/10.1084/jem.20111313.

70. Tan RH, Ke YD, Ittner LM, Halliday GM (2017) ALS/FTLD: experimental models and reality. Acta Neuropathol (Berl) 133:177-196. https://doi.org/10. 1007/s00401-016-1666-6.

71. Therrien M, Parker JA (2014) Worming forward: amyotrophic lateral sclerosis toxicity mechanisms and genetic interactions in Caenorhabditis elegans. Front Genet 5:85.

72. Uryu K, Nakashima-Yasuda H, Forman MS, Kwong LK, Clark CM, Grossman M, Miller BL, Kretzschmar HA, Lee VM-Y, Trojanowski JQ, Neumann M (2008) Concomitant TAR-DNA-binding protein 43 pathology is present in Alzheimer disease and corticobasal degeneration but not in other tauopathies. J Neuropathol Exp Neurol 67:555-564. https://doi.org/10.1097/ NEN.0b013e31817713b5.

73. Van Deerlin VM, Leverenz JB, Bekris LM, Bird TD, Yuan W, Elman LB, Clay D, Wood EM, Chen-Plotkin AS, Martinez-Lage M, Steinbart E, McCluskey L, Grossman M, Neumann M, Wu I-L, Yang W-S, Kalb R, Galasko DR, Montine TJ, Trojanowski JQ, Lee VM-Y, Schellenberg GD, Yu C-E (2008) TARDBP mutations in amyotrophic lateral sclerosis with TDP-43 neuropathology: a genetic and histopathological analysis. Lancet Neurol 7:409-416. https://doi. org/10.1016/S1474-4422(08)70071-1.

74. Verstraete E, Kuiperij HB, van Blitterswijk MM, Veldink JH, Schelhaas $H J$, van den Berg LH, Verbeek MM (2012) TDP-43 plasma levels are higher in amyotrophic lateral sclerosis. Amyotroph Lateral Scler 13:446-451. https:// doi.org/10.3109/17482968.2012.703208.
75. Volkening K, Keller BA, Leystra-Lantz C, Strong MJ (2018) RNA and protein interactors with TDP-43 in human spinal-cord lysates in amyotrophic lateral sclerosis. J Proteome Res. https://doi.org/10.1021/acs.jproteome.8b00126.

76. Watanabe S, Kaneko K, Yamanaka K (2013) Accelerated disease onset with stabilized familial amyotrophic lateral sclerosis (ALS)-linked mutant TDP-43 proteins. J Biol Chem 288:3641-3654. https://doi.org/10.1074/jbc.M112. 433615.

77. Weihl CC, Temiz P, Miller SE, Watts G, Smith C, Forman M, Hanson PI, Kimonis V, Pestronk A (2008) TDP-43 accumulation in inclusion body myopathy muscle suggests a common pathogenic mechanism with frontotemporal dementia. J Neurol Neurosurg Psychiatry 79:1186-1189. https://doi.org/10.1136/jnnp.2007.131334.

78. White MA, Kim E, Duffy A, Adalbert R, Phillips BU, Peters OM, Stephenson J, Yang S, Massenzio F, Lin Z, Andrews S, Segonds-Pichon A, Metterville J, Saksida LM, Mead R, Ribchester RR, Barhomi Y, Serre T, Coleman MP, Fallon JR, Bussey TJ, Brown RH, Sreedharan J (2018) TDP-43 gains function due to perturbed autoregulation in a Tardbp knock-in mouse model of ALS-FTD. Nat Neurosci 21:552-563. https://doi.org/10.1038/s41593-018-0113-5.

79. Winton MJ, Igaz LM, Wong MM, Kwong LK, Trojanowski JQ, Lee VM-Y (2008) Disturbance of nuclear and cytoplasmic TAR DNA-binding protein (TDP-43) induces disease-like redistribution, sequestration, and aggregate formation. J Biol Chem 283:13302-13309.

80. Yokota O, Davidson Y, Bigio EH, Ishizu H, Terada S, Arai T, Hasegawa M, Akiyama H, Sikkink S, Pickering-Brown S, Mann DMA (2010) Phosphorylated TDP-43 pathology and hippocampal sclerosis in progressive supranuclear palsy. Acta Neuropathol (Berl) 120:55-66. https://doi.org/10.1007/s00401010-0702-1.

\section{Ready to submit your research? Choose BMC and benefit from:}

- fast, convenient online submission

- thorough peer review by experienced researchers in your field

- rapid publication on acceptance

- support for research data, including large and complex data types

- gold Open Access which fosters wider collaboration and increased citations

- maximum visibility for your research: over $100 \mathrm{M}$ website views per year

At BMC, research is always in progress.

Learn more biomedcentral.com/submissions 